\title{
Searching for an oxygenation event in the fossiliferous Ediacaran of northwestern Canada
}

\author{
D.T. Johnston a,*, S.W. Poulton ${ }^{\text {b }}$, N.J. Tosca ${ }^{\text {c }}$, T. O'Brien ${ }^{\text {a }}$, G.P. Halverson ${ }^{\text {d }}$, D.P. Schrag ${ }^{\text {a }}$, F.A. Macdonald ${ }^{\text {a }}$ \\ a Department of Earth and Planetary Sciences, Harvard University, 20 Oxford Street, Cambridge, MA 02138, United States \\ b School of Earth and Environment, University of Leeds, Leeds LS2 9JT, United Kingdom \\ c Department of Earth Sciences, University of St. Andrews, St. Andrews, United Kingdom \\ d Department of Earth and Planetary Sciences/GEOTOP, McGill University, Montreal, QC H3A 2T5, Canada
}

\section{A R T I C L E I N F O}

Article history:

Accepted 30 August 2013

Available online $\mathrm{xxxx}$

\section{Keywords:}

Oxygen

Ediacaran

Animals

Biogeochemistry

Shuram

\begin{abstract}
A B S T R A C T
Late Neoproterozoic (Ediacaran) strata from northwestern Canada provide a thick and rich sedimentological record, preserving intercalated carbonates and shale extending from the 635 million year old Marinoan glacial deposits up through the $~ 541$ million year old Precambrian-Cambrian boundary. This region also holds one of the classic localities for the study of early animal life, with the ensuing suggestion that this temporal interval captures a gross change in the $\mathrm{O}_{2}$ content of the Earth's atmosphere. To test this hypothesis and bring records of northwestern Canada into line with other Ediacaran, fossil-bearing basins, we provide a detailed geochemical reconstruction from the Wernecke Mountains of the Yukon. Where possible, we also extend these records to the Ogilvie Mountains to the west and previously published data from the Mackenzie Mountains to the east.

Our work in the Wernecke Mountains is set against a composite $\delta^{13} \mathrm{C}$ record for carbonate that preserves three distinct Ediacaran isotope excursions, the lowermost of which (preserved in the Gametrail Formation) is a putative Shuram excursion equivalent. What emerges from a multi-proxy (Fe speciation, sulfur isotopes, major and trace element analyses) reconstruction is a picture of a persistently anoxic and ferruginous Ediacaran ocean. Notably absent is geochemical evidence for a prominent oxygenation event, an expectation given the appearance of animals and large swings in $\delta^{13} \mathrm{C}$. The new insight gained through these data challenges the idea of an Ediacaran jump in atmospheric oxygen, which in turn muddles the link between animal evolution and local geochemical environments.
\end{abstract}

(c) 2013 Elsevier B.V. All rights reserved.

\section{Introduction}

Interest in understanding Earth surface change in the late Proterozoic is rooted in trying to pinpoint the mechanisms and feedbacks associated with the origin of animals (Nursall, 1959; Cloud and Drake, 1968; Holland, 1984; Canfield et al., 2007; McFadden et al., 2008). Decades of work have combed Neoproterozoic successions and provide a robust paleontological roadmap for both the distribution of classic Ediacaran-type fossils as well as the underlying, earlier Ediacaran acritarch record (Hofmann et al., 1990; Narbonne and Aitken, 1990b; Fedonkin and Waggoner, 1997; Grey, 2005). Despite numerous models for the mechanisms driving the transition in biological systems (Canfield et al., 2007; Butterfield, 2009; Johnston et al., 2012b), the clues about the critical events that led to the emergence of animals remain at least partially locked within marine sediments. As a result, a suite of studies employing redox sensitive proxies have developed a framework whereby it is proposed that roughly coincident with the first animals, the deep ocean became

\footnotetext{
* Corresponding author.

E-mail address: johnston@eps.harvard.edu (D.T. Johnston).
}

oxygenated (Fike et al., 2006; Canfield et al., 2007; Canfield et al., 2008; Scott et al., 2008); this was Earth's canonical second great oxidation (Holland, 1984; DesMarais et al., 1992; Och and Shields-Zhou, 2012).

Assaying large-scale changes in atmospheric oxygen and geochemical cycles is classically a problem resolved through carbon isotope reconstructions (Broecker, 1970; Knoll et al., 1986; DesMarais et al., 1992; Fike et al., 2006; Johnston et al., 2012a). Here, the isotopic composition of carbonate and bulk organic carbon $\left(\delta^{13} \mathrm{C}_{\mathrm{carb}}\right.$ and $\delta^{13} \mathrm{C}_{\text {org }}$, respectively), when placed in a steady-state framework for the operation of the carbon cycle (Hayes et al., 1999), provides insight on the net production of oxygen. This $\mathrm{O}_{2}$ then propagates throughout surface environments, often leaving an imprint directly on $\mathrm{pO}_{2}$, but equally as important it controls sulfate delivery to the oceans and ferric oxide production on the continents (Holland, 1984; Holland et al., 1986; Hayes and Waldbauer, 2006; Holland, 2006). The net gain in these three oxidized reservoirs is the true measure of surface oxidation, and requires an expansion of the geochemical toolbox. Fortunately, the sulfur cycle can be indirectly tracked through isotopic reconstructions of sedimentary pyrite records and where possible, sulfates from evaporites, fluid inclusions, 
or that trapped within the carbonate lattice (Canfield and Teske, 1996; Canfield, 1998; Kampschulte and Strauss, 2004; Fike et al., 2006; Fike and Grotzinger, 2008). The influence of oxygen on global Fe budgets is more difficult to measure, as much of the ferric iron resides on the continents and in crustal materials. However, a refined extraction scheme provides a snapshot of iron cycling along a continental margin and serves as a powerful proxy for this budget. If the commonly posited increase in $\mathrm{pO}_{2}$ accompanies or slightly predates the Ediacaran appearance of animals, it should be detectable in the C-S-Fe geochemistry of strata in northwestern Canada.

The last decade has seen the pervasive application of a revised sedimentary iron extraction scheme capable of diagnosing the chemical structure of the marine water column (Poulton et al., 2004; Canfield et al., 2007; Canfield et al., 2008; Johnston et al., 2010; Li et al., 2010; Poulton et al., 2010; Planavsky et al., 2011; Johnston et al., 2012b). Through quantifying the partitioning of iron into different Fe-bearing minerals, it is possible to identify anoxia and further distinguish between ferruginous (ferrous iron bearing) and euxinic (sulfide bearing) conditions (Poulton and Canfield, 2005). Applied to shale facies from a number of Neoproterozoic basins, Fe geochemistry is revealing a complicated picture of marine redox between the end of the Marinoan glaciation roughly 635 million years ago (Ma) and the Precambrian-Cambrian boundary at $541 \mathrm{Ma}$. Reconstructions of fossiliferous basins in modern day Russia and Newfoundland provide internally consistent pictures of a water column that is sometimes oxygenated, but when anoxic, is always ferruginous (Canfield et al., 2007; Johnston et al., 2012b). As it relates to the origin of metazoans, up-section changes in the redox state of the EEP basin (targeting transitions that antedate or that are coincident with the first appearance of animals) are not profound, leading to the subtler hypothesis that the geochemical/redox stabilization of these environments may have also been important to the development of more complex life and ecologies (Johnston et al., 2012b). In contrast, condensed fossil-bearing stratigraphic sections from South China capture much more reducing marine conditions, with an almost episodic fluctuation between ferruginous and euxinic conditions (Shen et al., 2008a; Li et al., 2010) and even some indication of oxic conditions (Sahoo et al., 2012). Inferentially, marine chemical evolution through the Ediacaran appears to be a basin-by-basin affair (Kah and Bartley, 2011; Johnston et al., 2012b). Interestingly, and appreciating that taphonomy is also variable, the distribution of fossil-bearing assemblages is similarly heterogeneous.

Marine redox/geochemical variability will always reflect the interplay between equilibrium with the overburden of atmospheric oxygen and the move toward disequilibria in water column dissolved oxygen (DO) as a result of differential nutrient inputs and productivityremineralization regimes. How this context then feeds back on the link to animals and their unique physiological requirements is less clear, but must be related. Finding continuity between the geochemical and biological records through Ediacaran successions, especially those containing early metazoan records, requires high-resolution sampling, detailed and explicit correlations to fossil bearing horizons, and an expansion of geochemical reconstructions to include an understanding of sediment protolith.

One of the cornerstone Ediacaran paleontological records comes from mixed siliciclastic and carbonate sequences in northwestern Canada (Hofmann et al., 1990; Narbonne and Aitken, 1990b; Narbonne et al., 1994; Kaufman et al., 1997; Pyle et al., 2004; Macdonald et al., in this issue). Work on C-S-Fe in early Ediacaran stratigraphy from the Mackenzie Mountains has already hinted at evolving water column chemistry (Canfield et al., 2008; Shen et al., 2008b), but how that geochemical setting varies spatially (across the basin) or in time (up toward the Precambrian-Cambrian boundary) is unclear. In what follows we describe a detailed geochemical study, in conjunction with a revised stratigraphic context (Macdonald et al., in this issue), where we track major and trace element geochemistry and key isotopic metrics. Taken together, and when assimilated with data from other Ediacaran paleo-basins, a more lucid picture of Earth surface change and biological innovation is realized.

\section{Geological setting}

\subsection{The Wernecke Mountains}

In northwestern Canada, Ediacaran strata begin with micropeloidal dolomite of the Ravensthroat Formation (James et al., 2001), which caps a lowstand system tract at the top of the Cryogenian Keele Formation (Day et al., 2004) and glacigenic diamictite wedges of the Marinoan Icebrook Formation (Aitken, 1991b). The Ravensthroat is up to $30 \mathrm{~m}$ thick and is locally overlain by $\leq 10 \mathrm{~m}$ of limestone with pseudomorphosed aragonite fans of the Hayhook Formation (James et al., 2001). In the central Mackenzie Mountains, sea-floor barite discontinuously mantles the contact between the Ravensthroat and Hayhook formations, which together comprise the 'cap carbonate' (Hoffman and Halverson, 2011). Above the cap carbonate, the Ediacaran stratigraphy is a mix of siliciclastic and carbonate rocks (defined as the Sheepbed, Gametrail, Blueflower, and Risky formations, along with the informal, newly described Sheepbed carbonate and June beds (Macdonald et al., in this issue)) preserving large lateral variability in exposure and thickness (Fig. 1).

In the Wernecke Mountains, the lower Sheepbed Formation consists of shale with thin limestone interbeds and measures 350 m thick. Similar to exposures in the Mackenzie Mountains, the lower $\sim 100 \mathrm{~m}$ of shale is the darkest and most fissile and likely contain the maximum flooding surface (MFS) of the glacio-eustatic marine transgression. A distinct coarsening occurs roughly $180 \mathrm{~m}$ into the Sheepbed in our Wernecke section (same as Goz A from Pyle et al. 2004), where siltstone interbeds and platform-derived debris flows begin to appear. Upsection from this surface, limestone is increasingly more abundant and finally gives way to shallow water dolostone of the informal Sheepbed carbonate (Aitken, 1991a; Macdonald et al., in this issue). This carbonate unit was previously correlated with the Gametrail Formation (Pyle et al., 2004), but a recent examination of this correlation has identified an additional sequence boundary between the Sheepbed carbonate and the Gametrail Formation at its type locality (Macdonald et al., in this issue). The lower $\sim 150 \mathrm{~m}$ of the Sheepbed carbonate consists of a monotonous, massive dolomite with rare cross-bedding and giant ooids. This is capped by a major karst surface, and is succeeded by $\sim 40 \mathrm{~m}$ of coarse-grained sandstone and calc-arenite, which are assigned to the informal June beds. The overlying Gametrail Formation (peritidal member of Pyle et al. (2004)) consists of $\sim 50$ m of peritidal dolomite stacked in $\sim 10 \mathrm{~m}$ thick parasequences capped by exposure surfaces. These surfaces culminate in a major unconformity that defines the base of the Blueflower Formation (Yuletide member of Pyle et al. (2004)) and is incised by multiple beds of cobble-clast quartzite conglomerate. The conglomerates are succeeded by a major flooding surface and shale with interbedded normally graded beds of sand and silt (interpreted as turbidites) that host simple bedding plane traces and Ediacaran disk fossils (Narbonne and Aitken, 1990a). The Blueflower Formation shallows upwards into hummocky crossstratified sandstone and pink sandy dolomite of the Risky Formation. The top of the Risky Formation is marked by a karstic unconformity. Above this unconformity, small shelly fossils and a diverse microfossil assemblage have been described in phosphatic carbonates in the Ingta Formation near the southern Wernecke Mountain sections at Goz C and D (Nowlan et al., 1985; Pyle et al., 2006). This stratigraphic framework is presented in Fig. 1 and discussed in detail in a companion study (Macdonald et al., in this issue).

\subsection{Correlation to the Mackenzie and Ogilvie Mountains}

Correlative Ediacaran strata have been measured both to the east (in the central and southeast Mackenzie Mountains) and to the west (Ogilvie 


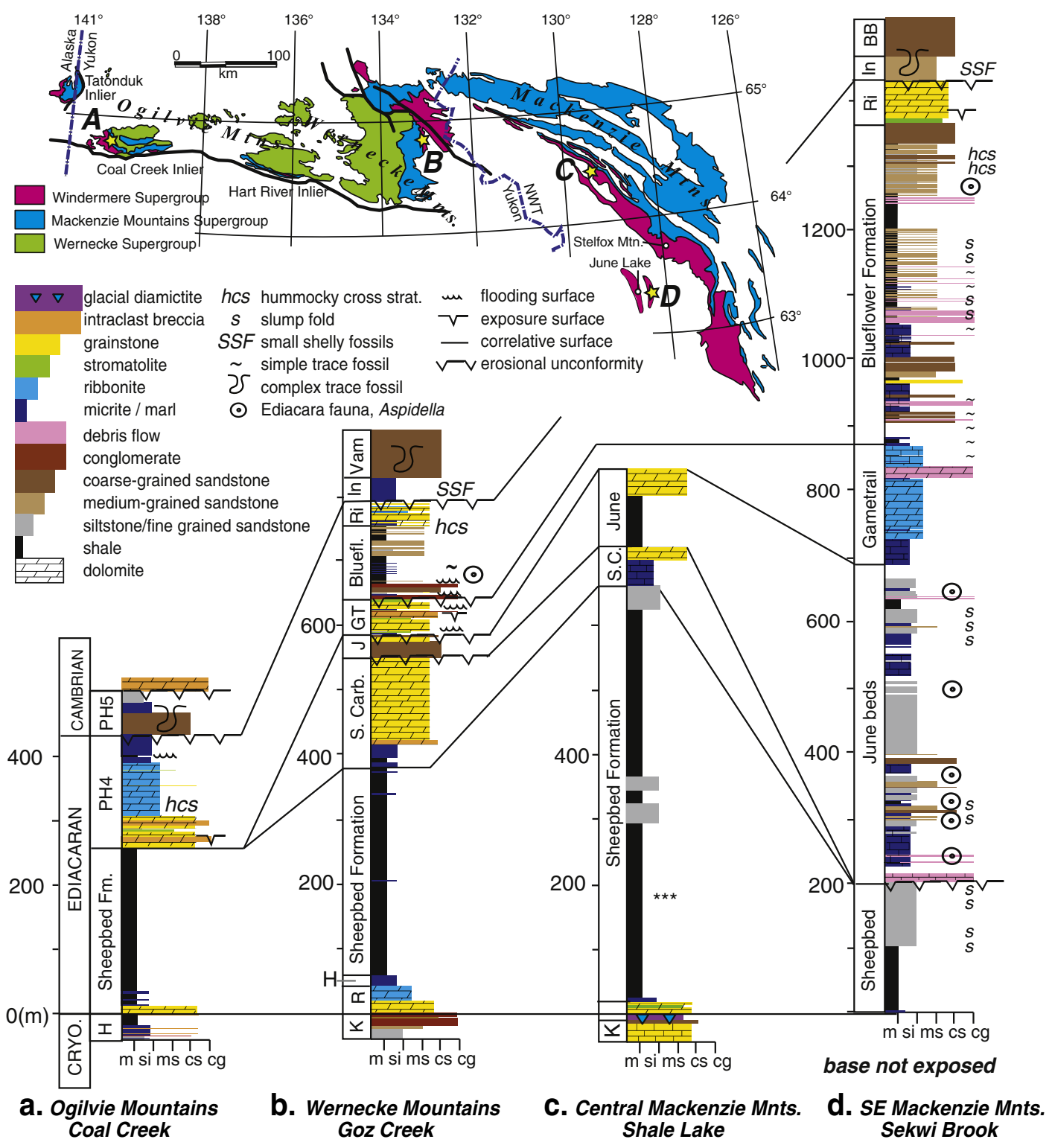

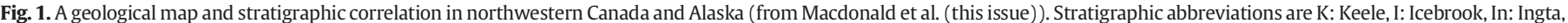

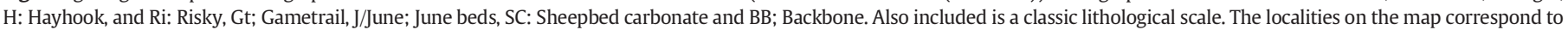

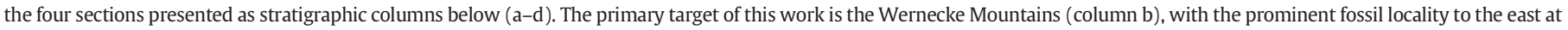
Sekwi Brook.

Mountains). The details of these correlations are published elsewhere (Macdonald et al., in this issue) with key features highlighted below. Near Shale Lake in the central Mackenzie Mountains, the Sheepbed Formation (the target formation of this study) is between 450 and $700 \mathrm{~m}$ thick and dominated by black shale with minor fine-grained sandstones to siltstone interbeds interpreted as turbidites (Fig. 1). Recent workers reconstructed the C-S-Fe systematics in this section and suggested a shift in Fe-speciation ratios - from anoxic to oxic - at $\sim 180 \mathrm{~m}$ (Shen et al., 2008b). The general position of this geochemical transition roughly corresponds to a coarsening in which siltstone interbeds become more common. In the southeast Mackenzie Mountains, at Sekwi Brook the lower Sheepbed Formation is incised by a cobble-clast debris flow that contains abundant giant ooids and has a sharp, erosive base. Above this contact, the background sediment is dominated by carbonate-rich shale and the first appearance datum of the Ediacaran Aspidella occurs within $15 \mathrm{~m}$ on the sole of a normally graded fine-grained sandstone bed. The overlying middle member as described by Dalrymple and Narbonne
(1996) consists of carbonate-rich shale and siltstone with common Aspidella (Narbonne and Aitken, 1990a). Ediacaran biota is preserved primarily on the bottoms of fine-grained sandstone beds interpreted to represent the Bouma $\mathrm{C}$ turbidite sub-division. Departing from previous correlations that assigned these strata to the Sheepbed Formation (Narbonne and Aitken, 1990a; Shen et al., 2008b), Macdonald et al. (in this issue) assigned the Ediacaran-bearing, carbonate-rich strata above the surface at $200 \mathrm{~m}$ to the June beds, which elsewhere rest above the Sheepbed carbonate, separated by a major sequence boundary. This assignment invalidates the correlation of the shift in Fe speciation of Shen et al. (2008b) with the appearance of Ediacaran biota. Finally, in the Coal Creek inlier of the Ogilvie Mountains, the Sheepbed Formation is $\sim 250 \mathrm{~m}$ thick and is succeeded by $\sim 25 \mathrm{~m}$ of massive white to buffcolored dolostone with pervasive cements and an additional $\sim 100 \mathrm{~m}$ of thinly bedded, pink dolo-ribbonite with hummocky cross-stratification, grainstone, and stromatolites (unit PH 4). The dolomites are succeeded by $\sim 10 \mathrm{~m}$ of dark-colored, nodular, organic-rich limestone, which 
resembles the lower Blueflower Formation at Sekwi Brook. This unit is unconformably overlain by Cambrian, fossil-bearing siliciclastic strata (unit PH5).

\section{Methods}

Carbon, sulfur, and iron data were generated through standard techniques. Carbonate carbon content (\% carbonate) was quantified by loss through an acid dissolution, which also isolated a residue of siliciclastic material and organic matter. These mass fractions were further distinguished through quantifying yields on a Carlo Erba Elemental Analyzer linked to a Thermo Finnigan Delta- $V$ configured in continuous flow mode, which also yielded $\delta^{13} \mathrm{C}_{\mathrm{org}}$. The isotopic composition of carbonate $\left(\delta^{13} \mathrm{C}_{\mathrm{carb}}\right)$ is from a companion study (Macdonald et al., in this issue). Uncertainties for $\delta^{13} \mathrm{C}$ are $0.2 \%$, and better than $0.05 \mathrm{wt} . \%$ for TOC.

The sedimentary iron cycle is evaluated through an operationally defined extraction protocol optimized for siliciclastic rocks and marine sediments (Poulton and Canfield, 2005). This procedure isolates the biogeochemically reactive iron minerals (binned as oxides [ $\left[\mathrm{Fe}_{\mathrm{ox}}\right]$, mixed valence $\mathrm{Fe}$ minerals such as magnetite $\left[\mathrm{Fe}_{\mathrm{mag}}\right]$, and ferrous iron carbonates $\left.\left[\mathrm{Fe}_{\mathrm{carb}}\right]\right)$. Extracted separately, but still related are iron sulfide minerals $\left(\mathrm{Fe}_{\mathrm{py}}\right.$ ) (Canfield et al., 1986). The sum of these extractions represents the highly reactive pool (FeHr). Total Fe content and other major and trace element data were analyzed commercially (SGS, Alberta Canada) by ICP-AES on bulk samples dissolved in $\mathrm{HF}-\mathrm{HNO}_{3}-\mathrm{HClO}_{4}$ solution.

Carbonates from the Sheepbed carbonate and overlying Gametrail Formation were also processed for carbonate-associated sulfate according to established protocols (Burdett et al., 1989; Gill et al., 2007). These sulfate isolates and pyrites extracted from both the residues associated with the CAS extraction and from siliciclastic pyrite iron $\left(\mathrm{Fe}_{\mathrm{py}}\right)$ where analyzed through combustion via a Costech Elemental Analyzer linked to a Delta V in continuous flow mode (measured as $\mathrm{SO}-\mathrm{SO}_{2}$ ) with a precision of $<0.2 \%$ in $\delta^{34} \mathrm{~S}$.

Samples from northwestern Canada were also analyzed (and data manipulated) to determine the chemical index of alteration, or CIA This metric tracks the preferential loss of particular cations through weathering reactions: $\mathrm{CIA}=\left[\mathrm{Al}_{2} \mathrm{O}_{3} /\left(\mathrm{Al}_{2} \mathrm{O}_{3}+\mathrm{CaO}^{*}+\mathrm{Na}_{2} \mathrm{O}+\mathrm{K}_{2} \mathrm{O}\right)\right]$ (McLennan and Taylor, 1991; McLennan, 1993; Fedo et al., 1995; Tosca et al., 2010). For these calculations, oxide fractions are determined from ICP data and corrections are taken from established methods. Namely, for $\mathrm{CaO}^{*}$ in siliciclastics with variable mass fractions of carbonate, the silicate $[\mathrm{CaO}]$ fraction is fixed to $\left[\mathrm{Na}_{2} \mathrm{O}\right]$ (Kronberg et al., 1986).

\section{Results}

Carbon isotope values in carbonate and organic matter vary upsection, with clear distinction between individual formations, despite some lithofacies dependence (Fig. 2). Carbonate $\delta^{13} \mathrm{C}$ values are typically depleted through the Hayhook cap carbonate and into the lowermost Sheepbed Formation, but appear to recover steadily back to $\sim 5 \%$ by the Sheepbed carbonate unit, consistent with previous studies of this and other basal Ediacaran successions (James et al., 2001; Hoffman et al., 2007). A negative $\delta^{13} C_{\text {carb }}$ excursion is recorded in the Gametrail Formation, with two additional anomalies preserved within the overlying Blueflower and Risky formations. The Gametrail Formation excursion preserves a dramatic and coherent negative $\delta^{13} \mathrm{C}_{\text {carb }}$ anomaly of $>10 \%$ (from +4 to $-7 \%$ ), and recovers to near $0 \%$ o before the Gametrail-Blueflower sequence boundary. Sparse $\delta^{13} \mathrm{C}_{\text {carb }}$ data from the Blueflower Formation preserves a negative anomaly down to $-8 \%$, and after a recovery to $-2 \%$, another depletion event down to $<-5 \%$ in the Risky Formation. Carbon isotope data from PH4 in the Ogilvie Mountains are also highly variable but systematic (Fig. 2), with $\delta^{13} \mathrm{C}_{\mathrm{carb}}$ beginning

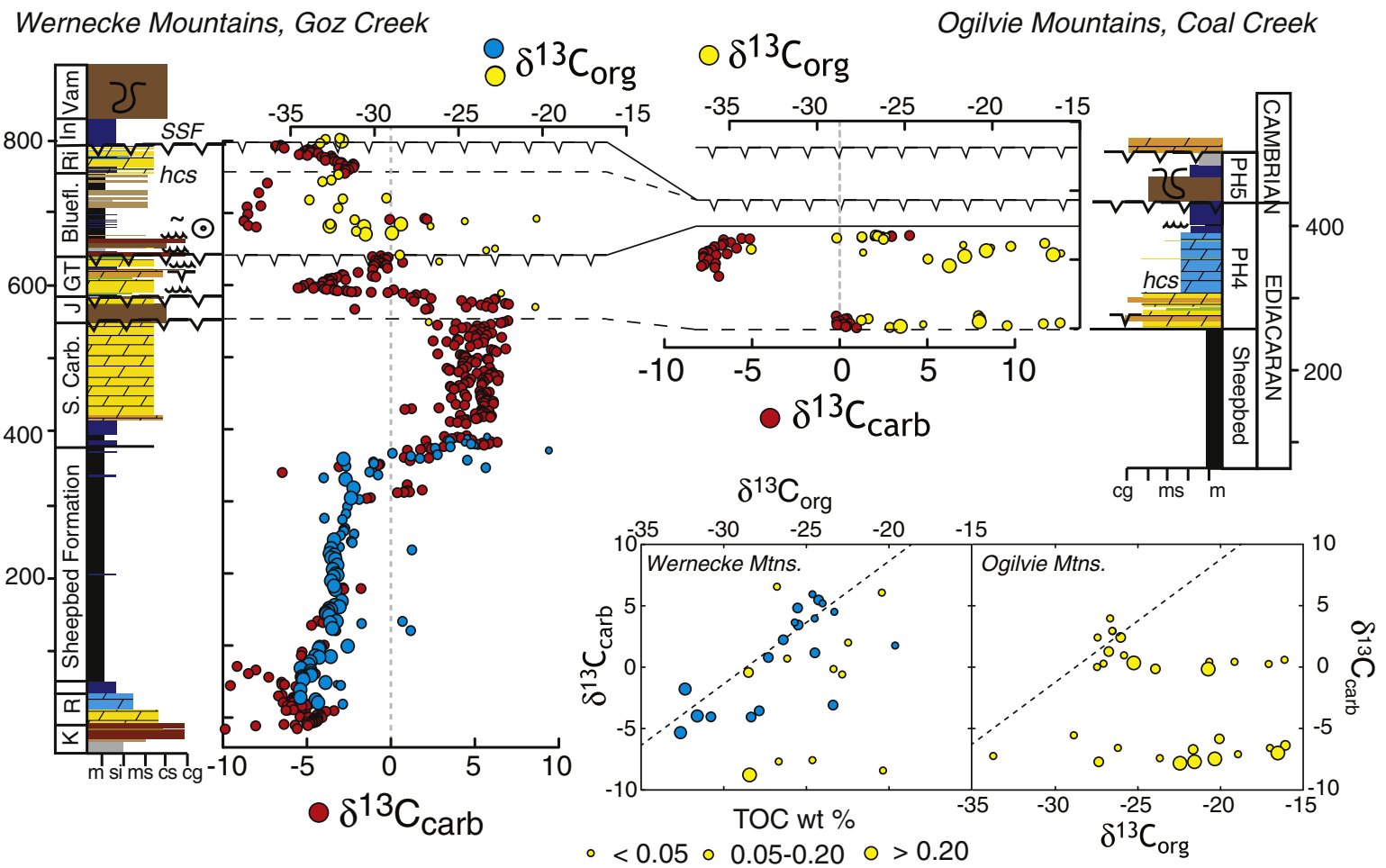

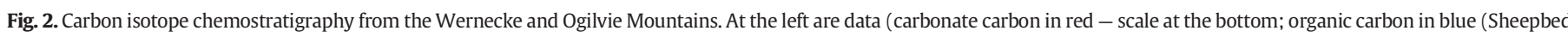

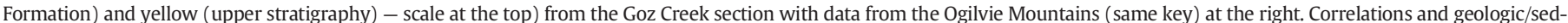

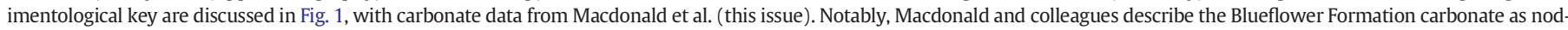

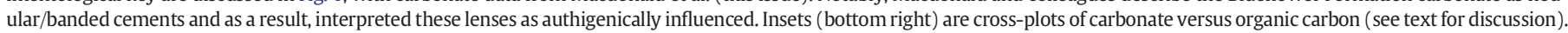
(For interpretation of the references to color in this figure legend, the reader is referred to the web version of this article.) 
near $0 \%$ before plummeting to $-8 \%$ and recovering up-section back to $+4 \%$. Based on new correlations (Macdonald et al., in this issue), the Gametrail Formation excursion post-dates the Sheepbed transgressive-regressive sequence and is tentatively regarded as time equivalent to the global Shuram-Wonoka excursion (Grotzinger et al., 2011).

The isotopic composition of organic matter from the Wernecke and Ogilvie Mountains is also presented (Fig. 2). Organic matter from the Sheepbed Formation in the Wernecke Mountains is consistently offset from carbonate by roughly $-30 \%$. The Blueflower and Gametrail formations preserve $\delta^{13} \mathrm{C}_{\text {org }}$ values that do not vary systematically with $\delta^{13} \mathrm{C}_{\text {carb }}$, and range widely from $-20 \%$ o to $-35 \%$. Similarly, total organic carbon contents are quite variable. In the Sheepbed Formation, TOC is low at the base (0.1 wt.\%) with a pronounced enrichment of $>0.4$ wt.\% between 100 and $225 \mathrm{~m}$. In the uppermost Sheepbed Formation, values are less than 0.2 wt.\%. In the overlying Blueflower Formation, similar TOC concentrations are preserved, with 2 samples preserving anomalous enrichments of $>0.4 \mathrm{wt} . \%$. In the Blueflower Formation, the $\delta^{13} \mathrm{C}_{\text {org }}$ is highly variable with most samples falling between $-30 \%$ and $-15 \%$. As in the Wernecke Mountains, the TOC values are significant but highly variable in the Ogilvie Mountains, with a mean of $\sim 0.1 \mathrm{wt} . \%$.

Iron speciation data (Fig. 3) for siliciclastic samples (Sheepbed and Blueflower formations) suggest that most of the reactive Fe is locked within iron carbonates $(0.7 \pm 0.4 \mathrm{wt} . \%)$ or oxide phases
$(1.0 \pm 0.4 \mathrm{wt} . \%)$. Magnetite and pyrite iron represent only minor contributions $(0.11 \pm 0.07 \mathrm{wt} . \%$ and $0.10 \pm 0.08 \mathrm{wt} . \%$, respectively). The $\delta^{34} \mathrm{~S}$ data from pyrite span a large range of values in the Sheepbed Formation (Fig. 4), but are stratigraphically coherent: more depleted isotopic compositions characterize the lower portion of the unit $(<-20 \%)$, systematically increasing toward more enriched values (>20\%) upsection and leveling off at $\sim 250 \mathrm{~m}$. Above this horizon, sulfides are variable (generally between 10 and $30 \%$ ) but are always positive. Sulfates extracted from the Sheepbed carbonate contain consistent CAS values (in $\delta^{34} \mathrm{~S}$ ) of $30 \%$.

Major and trace element chemistry through the Wernecke Mountains section broadly tracks lithology. Redox sensitive elements (e.g., Mn, V, $\mathrm{Zn}, \mathrm{Cr}$ ) and those that participate more actively in biogeochemistry (P) show some systematic variability. Major element chemistry is also variable, in part recorded by the chemical index of alteration: CIA (Fig. 5).

\section{Discussion}

\subsection{The Ediacaran carbon cycle}

Understanding the nature of the Ediacaran ocean-atmosphere system begins with a critical evaluation of the behavior of the carbon cycle. In many ways, the pattern of $\delta^{13} \mathrm{C}_{\text {carb }}$ through the basal Hayhook-Icebrook cap carbonate sequence and overlying Sheepbed Formation is typical of post-glacial successions globally (Halverson
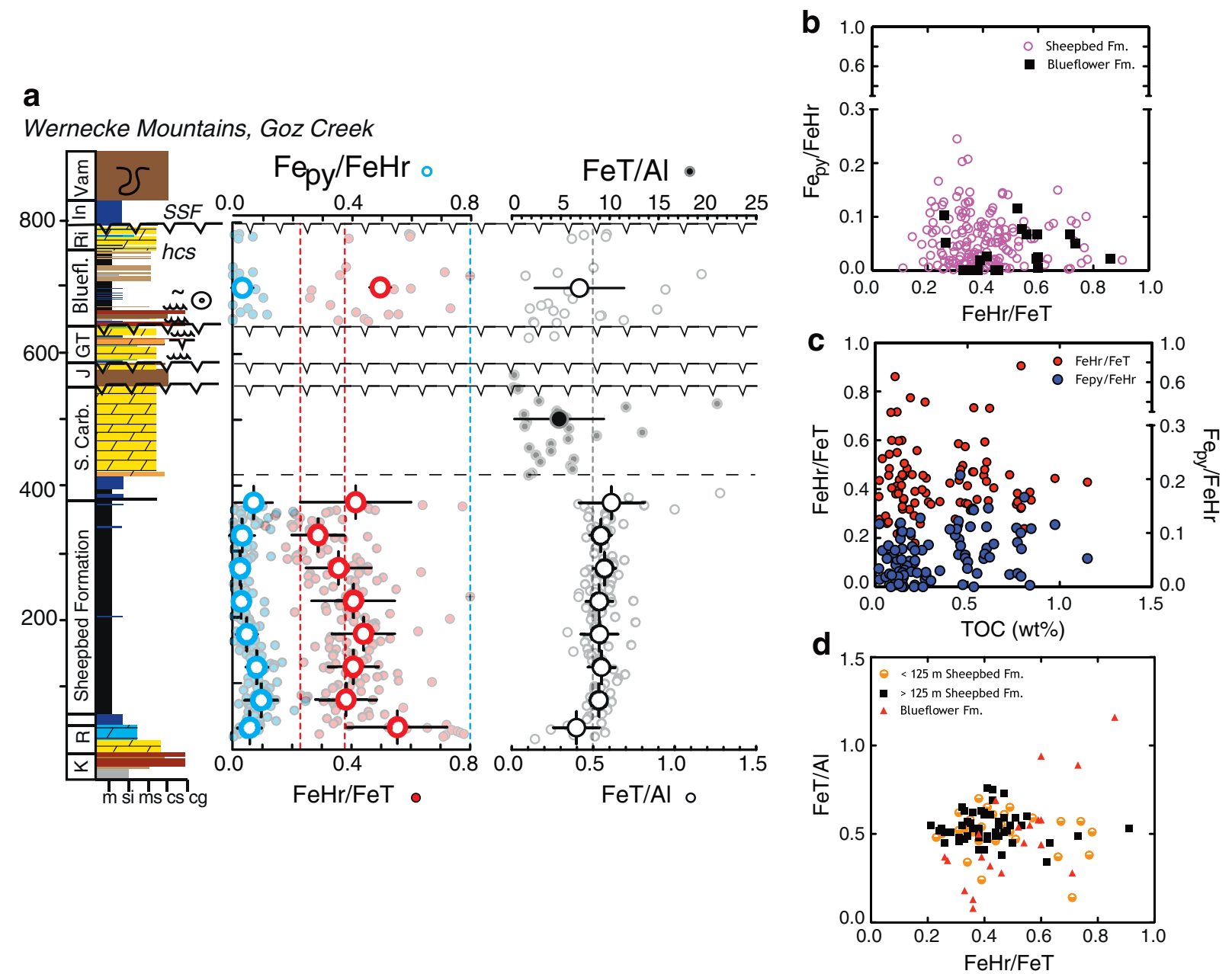

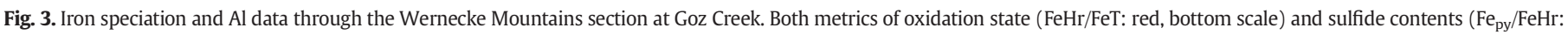

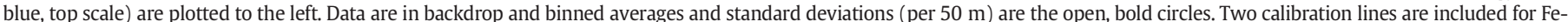

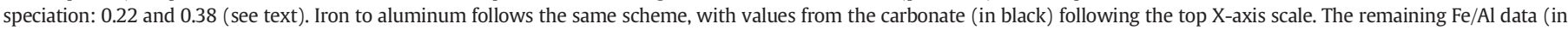

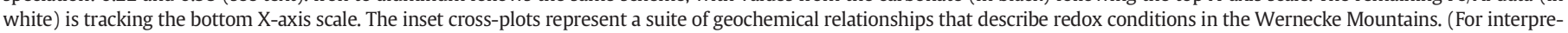
tation of the references to color in this figure legend, the reader is referred to the web version of this article.) 

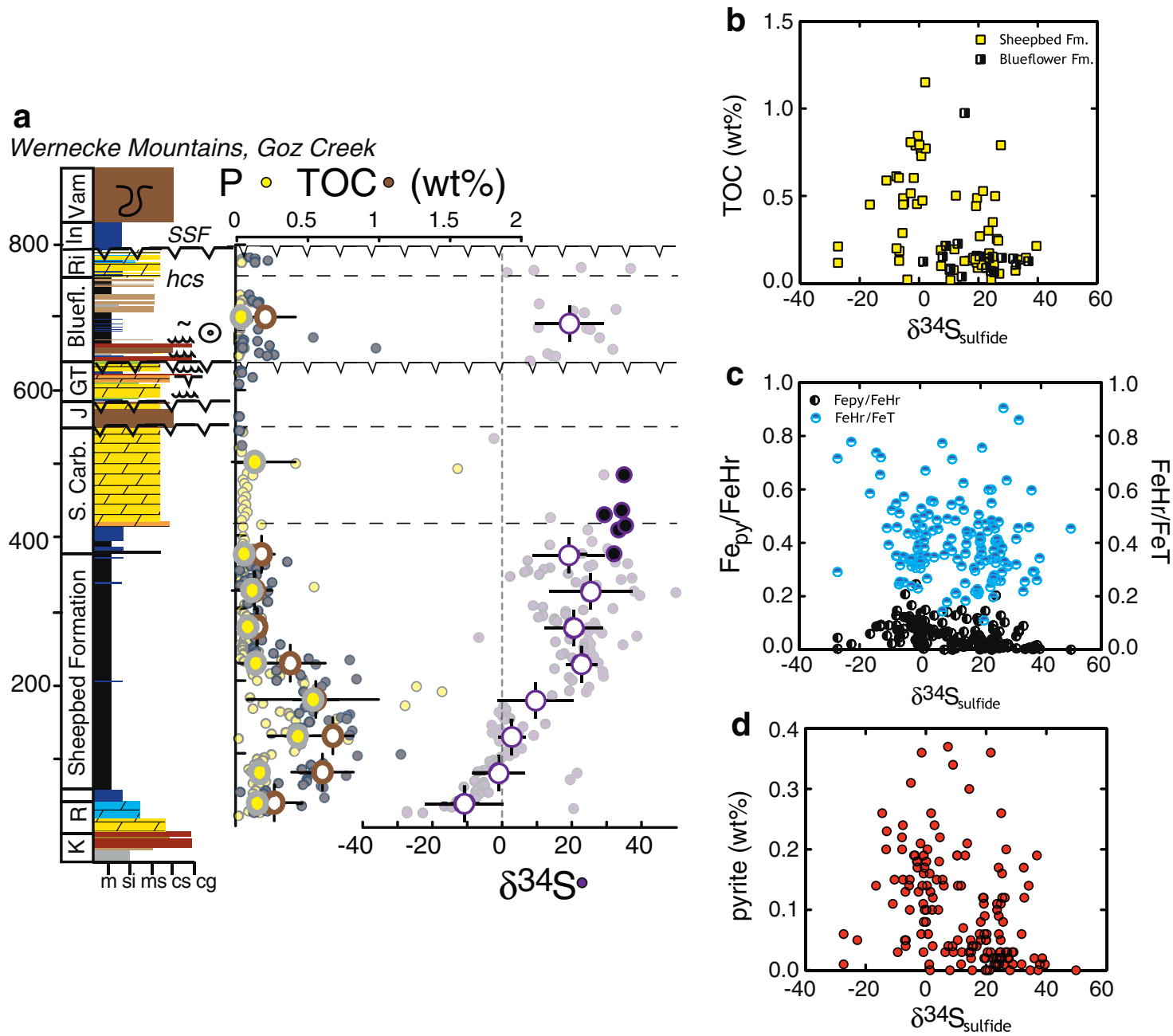

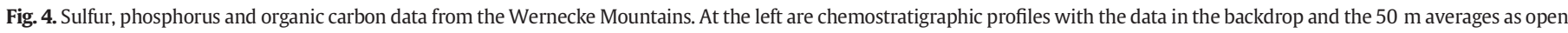

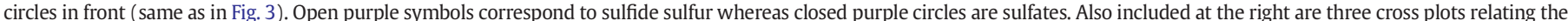

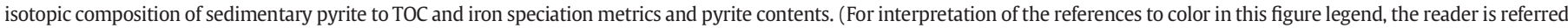
to the web version of this article.)

et al., 2005). Here, depleted and stable $\delta^{13} \mathrm{C}_{\text {carb }}(\sim-5 \%)$ in the Hayhook Formation continue into the basal Sheepbed Formation (Fig. 2), which records a modest isotopic enrichment upsection ( 0.1\% per $10 \mathrm{~m})$.
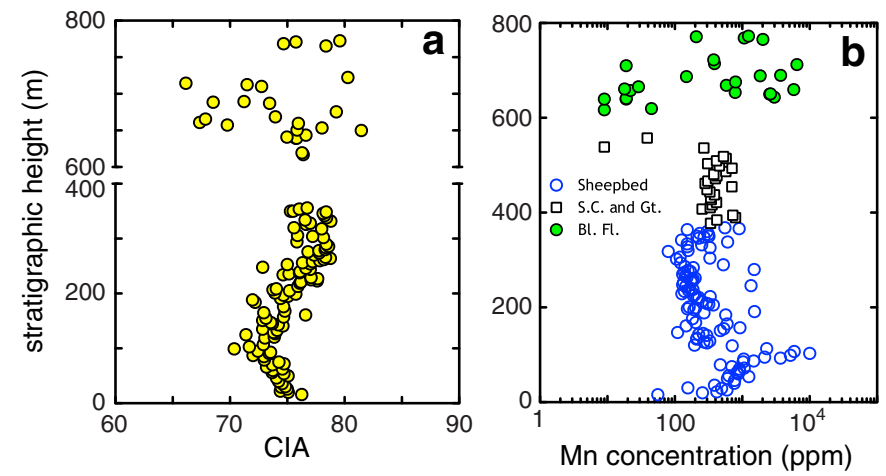

Fig. 5. Two chemical metrics critical to the interpretation of the Wernecke Mountain siliciclastic fluxes. CIA aids in the interpretation and impact of chemical weathering on source sediments, but can also be affected by diagenetic influences on $\mathrm{Ca}^{2+}, \mathrm{Na}^{+}$or $\mathrm{K}^{+}$. Second is a notable enrichment at Mn at the MFS, which corresponds to an inflection in the CIA profile. Both CIA and Mn show a large range of values in the Blueflower, but a coherent signal in the Sheepbed Formation. See text for discussion.
This gradual change is punctuated by a larger and terminal increase to roughly $6 \%$ \% $\sim 1 \%$ o per $10 \mathrm{~m})$ through the transition into the Sheepbed carbonate. The apparent disparity in the rate of isotopic change may be an artifact of fluctuations in sedimentation rates rather than a true regime shift. The progressive enrichment through the highstand and ensuing shallowing-upward sequence are neatly tracked by $\delta^{13} C_{\text {org }}$ values from shale and (where available) carbonate, which are systematically offset by roughly $30 \%$ (Fig. 2). Interestingly, total organic carbon contents vary with a distinct maximum at $\sim 120 \mathrm{~m}$ (Fig. 4), with no effect on $\delta^{13} \mathrm{C}_{\text {org }}$ (Johnston et al., 2012a). Estimates for the timescale of deposition for the entire post-glacial sequence (Hayhook-Sheepbed) range from a maximum duration of $635 \mathrm{Ma}-580 \mathrm{Ma}$, to a shorter duration of a few million to tens of million years (Macdonald et al., in this issue).

The sheer abundance of carbon isotopic variability within the middle and upper stratigraphy of the Wernecke Mountains, although stratigraphically coherent, requires attention. The most prominent feature of roughly time correlative strata to the Gametrail Formation is the ca. $580 \mathrm{Ma}$ Shuram-Wonoka excursion (Grotzinger et al., 2011). Like in the Wernecke and Ogilvie Mountains, a 10\% negative $\delta^{13} \mathrm{C}_{\text {carb }}$ excursion reaching a minimum value of $-6 \%$ is broadly consistent with the record in Oman (Fike et al., 2006), Australia (Calver, 2000), Namibia (Workman et al., 2002), western USA (Corsetti and Kaufman, 2003), and South China (McFadden et al., 2008). Notably, the $\delta^{13} \mathrm{C}$ signal in the Ogilvie Mountains is 2\% offset 
from the Wernecke Mountains toward more depleted values suggesting a reverse basinal gradient of some variety or that the two are not correlative (Macdonald et al., in this issue). In viewing the Gametrail Formation excursion as representative of this basin, this fits with a correlation to the Shuram-Wonoka excursion; an assignment that is more thoroughly described in Macdonald et al. (in this issue), but whose consequences for global surface environments are explored herein.

The uppermost excursion in the Risky Formation of the Wernecke Mountains shares some similarities with the Precambrian-Cambrian boundary excursion (Knoll and Walter, 1992). However, the isotope excursion in the Blueflower Formation is more difficult to uniquely correlate or extend to a global framework, as it is developed in carbonate cements within siliciclastic strata. Carbonate preserved within these settings likely reflects an imprint of both global DIC adopted from overlying seawater and from local (sedimentary) remineralization reactions (Schrag et al., 2013). Why the Blueflower is influenced by authigenic carbonate whereas other siliciclastic strata are less affected (see the Sheepbed Formation, for instance) is most probably the result of the local controls on remineralization and the openness of local pore waters to overlying seawater (Schrag et al., 2013).

One means of testing the fidelity of these interpretations is through an examination of $\delta^{13} \mathrm{C}_{\text {org }}$ within both the carbonate and siliciclastic units. The early Ediacaran Sheepbed Formation preserves a snapshot of typical carbon isotopic behavior, where $\delta^{13} \mathrm{C}_{\mathrm{org}}$ tracks carbonate carbon closely (Knoll et al., 1986; Hayes et al., 1999; Johnston et al., 2012a). Conversely, the upper portion of the stratigraphy (Gametrail through Blueflower Formation) does not conform to this simple behavior, as the isotopic composition of the carbonate and organic carbon appears to be varying independently. As we interpret the Blueflower Formation excursion as the product of secondary influences, no concrete prediction exists for coincident $\delta^{13} \mathrm{C}_{\mathrm{org}}$. This is not the case for the putative Shuram anomaly in the Gametrail Formation or the boundary excursion in the Risky Formation. For the Shuram-like excursion in the Ogilvie Mountains, the isotopic composition of the organic matter is disjoined from the carbonate isotopes, much like that observed in Oman and South China (Fike et al., 2006; McFadden et al., 2008). Unlike that preserved elsewhere, however, the $\delta^{13} \mathrm{C}_{\mathrm{org}}$ from the Ogilvie Mountains is highly variable rather than being remarkably invariant (Fike et al., 2006; McFadden et al., 2008). Setting aside for the moment the interpretation of $\delta^{13} \mathrm{C}_{\text {carb }}$, it is difficult to uniquely diagnose the source(s) of huge variability in organic matter through the Gametrail, Blueflower and Risky formations. One can envision fluctuating contributions from contemporaneous primary production, selective remineralization, detrital fluxes (assayed through determining protolith) and perhaps the later delivery of organic rich fluids, with only primary organic matter tracking the isotopic composition of DIC (and hence preserving the same excursion as $\delta^{13} C_{\text {carb }}$ ) (Johnston et al., 2012a; Schrag et al., 2013).

The primary variability in $\delta^{13} \mathrm{C}_{\text {carb }}$ must be interpreted against the backdrop of uncertainty about the sources and mechanisms influencing the $\delta^{13} \mathrm{C}_{\mathrm{org}}$. The traditional means of interpreting carbonate carbon isotopic excursions invokes changes in the fractional burial of organic matter, $f_{\text {org. }}$ That is, given isotopic mass balance (Hayes et al., 1999; Johnston et al., 2012a), the isotopic difference between carbon outputs (commonly simplified as carbonate and organic carbon) must sum back to the composition of mantle inputs. Using the stoichiometry of primary production, this estimated flux is roughly equivalent to the production of $\mathrm{O}_{2}$ (Knoll et al., 1986; Bristow and Kennedy, 2008). Confidence in $f_{\text {org }}$ is lessened, however, when $\delta \delta^{13} C_{\text {carb }}$ plunges below the oft-assumed mantle input value of $-6 \%$ (Grotzinger et al., 2011 ) or remains at significantly elevated values for $10^{7}-10^{8}$ years (Halverson et al., 2005). This framework underlies hypotheses about large-scale 'events' as driving the profound isotopic change preserved within Ediacaran records, most notably the Shuram excursion (Rothman et al., 2003; Fike et al., 2006). Both a change in $f_{\text {org }}$ or a massive remineralization 'event' would carry direct and predictable consequences for oxidant budgets (Bristow and Kennedy, 2008).
Redox reconstructions serve as a proxy for surface oxidizing capacity (i.e. the availability of $\mathrm{O}_{2}, \mathrm{SO}_{4}^{2-}, \mathrm{NO}_{3}^{-}, \mathrm{Fe}^{3+}$ ) and represent a test of these models. Put differently, if Shuram-like excursions from the Wernecke and Ogilvie mountains were in fact reflecting a real change in the oxidation state of the world's oceans (and atmosphere) - through a massive remineralization event (consuming oxidants) or through a crash in $f_{\text {org }}$ (turning down oxidant production) - redox sensitive metrics should record a change. Conversely, if for instance the Gametrail Formation $\delta^{13} \mathrm{C}_{\text {carb }}$ excursion is reflecting the ingrowth of significant authigenic carbonate precipitation, which alters the overall isotopic mass balance underlying $f_{\text {org }}$ (Schrag et al., 2013), then a massive change in oxidants is not required. We perform this test below.

\subsection{The behavior of the early Ediacaran Fe cycle}

The redox character of Ediacaran ocean chemistry is queried by investigating biogeochemically cycled elements, particularly iron and sulfur. Recall that Earth's total oxidant budget in the modern is dominated by ferric iron and sulfate, with $\mathrm{pO}_{2}$ coming in third in sheer oxidizing capacity (Hayes and Waldbauer, 2006). To assay Fe budgets in the past, speciation techniques track the accumulation of mobile, highly reactive iron $(\mathrm{FeHr})$ enrichments in anoxic environments $(\mathrm{FeHr} / \mathrm{FeT}>0.38$ is deemed anoxic and $<0.22$ as oxic (Raiswell and Canfield, 1998; Poulton and Raiswell, 2002)). Related to this, a predominance of $\mathrm{FeHr}$ residing in pyrite $(>\sim 70-80 \%)$ suggests euxinic conditions (Anderson and Raiswell, 2004; Poulton and Canfield, 2011), whereas lower sulfide contents (FeHr in carbonates and oxides) are indicative of a ferruginous water column (Poulton et al., 2004). For sulfur, isotopic reconstructions serve as a complementary tool in assaying the behavior of the biosphere and the generation of biogenic iron sulfides. Both approaches carry implications for the location and dominance of particular heterotrophic metabolisms, namely dissimilatory sulfate and iron reduction, which in turn inform environmental conditions.

We begin by interpreting siliciclastic sediments from the Ediacaran of the Wernecke Mountains. Near the base of the Sheepbed Formation, $\mathrm{FeHr} / \mathrm{FeT}>0.38$ and $\mathrm{Fe}$ py/ $\mathrm{FeHr}$ is much less than 0.8 (Fig. 3). The conventional interpretation would then point to a generally anoxic and ferruginous water column. As deposition of the lowermost $\sim 100 \mathrm{~m}$ of the Sheepbed Formation may have been relatively rapid, considering that the necessary accommodation space was developed during glacial times, the anoxia signal may reflect a transient state associated with the ventilation of the post-glacial ocean. Throughout the remainder of the Sheepbed shale, FeHr/FeT straddles the geochemical threshold defining anoxia (mean $\mathrm{FeHr} / \mathrm{FeT} \approx 0.4$ ). Although the mean values throughout fall near the calibrated anoxia threshold, the variability within the any given stratigraphic interval does allow for the possibility of intervening (and transient) oxic conditions. Values near the oxic threshold (leftmost red dashed line in Fig. 3 ) become more common toward the top of the Sheepbed, perhaps suggesting an influence from a well mixed and oxygenated surface-ocean. The Sheepbed can then be interpreted as recording a background anoxic, ferruginous deep-water condition that may be punctuated by occasional communication with the surface ocean. This nicely fits with the sequence stratigraphic architecture.

After passing through the Sheepbed carbonate and the carbonate dominated Gametrail Formation, siliciclastic sedimentation returns in the Blueflower Formation. The Blueflower Formation consists of multiple small-scale sequences superimposed on a larger shallowing upward sequence (Macdonald et al., in this issue), and is relatively thin in the Wernecke Mountains, but thickens to the southwest into the Selwyn Mountains (Fig. 1). Above the sandstone and conglomerate that constitute the base of the succession, the unit is shale and siltstone dominated and transitions upward into coarser grained siltstone and sandstone. Importantly, it is within the Blueflower Formation that the first Ediacaran biota appears in the Wernecke Mountains (Pyle et al., 2004). One 
might expect then, given the oxygen requirements of animals (Raff and Raff, 1970; Runnegar, 1991), that redox measures from the Blueflower Formation would all point toward abundant $\mathrm{O}_{2}$ at this time. In contrast to this prediction, the mean $\mathrm{FeHr} / \mathrm{FeT}$ far exceeds 0.4 with no samples falling below the oxic threshold (Fig. 3). Despite the similar suggestion of predominant anoxia and low sulfide contents in the Blueflower Formation, the distribution of Fe is quite different from the Sheepbed Formation. The Sheepbed Formation preserves largely invariant FeT contents, with iron carbonate representing the primary $\mathrm{FeHr}$ phase. The Blueflower Formation, on the other hand, carries a wide range of FeT with oxides being the dominant phase. Facies within the Blueflower Formation, which include hummocky cross stratification, suggest a near shore environment, perhaps indicating that riverine-derived Fe-oxides may have been scavenged in a fashion similar to today (Poulton and Raiswell, 2002). Alternatively, the source of sediments (protolith) or the weathering regime as a whole (sheer mass flux) may be different between the two units. If true, this would also impact local sediment biogeochemistry and may help explain the distribution of authigenic carbonate.

Sequence stratigraphy and an expanded geochemical toolbox help inform the depositional environment of the post-Marinoan (earliest Ediacaran) Sheepbed Formation. The deposition of the lower $\sim 100 \mathrm{~m}$ of the Sheepbed Formation followed the alkalinity pulse that generated the cap carbonate (Higgins and Schrag, 2003) and may have been relatively rapid. This is succeeded by a MFS approximated within 100 to $180 \mathrm{~m}$ from the base and a shallowing upward sequence that grades into the Sheepbed carbonate. Similar to Fe speciation, Fe/Al ratios track net iron enrichment over a crustal background composition (Lyons and Severmann, 2006). Iron-aluminum ratios are lowest in the basal Sheepbed Formation $(<0.5)$, but quickly increase and stabilize at $\sim 0.5$ for the remainder of the siliciclastic deposition: values generally indicative of typical oxic marine deposition. The slightly more depleted $\mathrm{Fe} / \mathrm{Al}$ values captured during initial transgression may reflect that the terrestrial input of unreactive Fe was lower than average shale in this locality (driving $\mathrm{Fe} / \mathrm{Al}$ down and $\mathrm{FeHr}$ / $\mathrm{FeT}$ up). If true, the then maximum of $\mathrm{FeHr} / \mathrm{FeT}$ in the basal Sheepbed Formation would be an artifact of weathering through this interval and not reflect a marine condition different from the overlying middle and upper Sheepbed Formation, where both $\mathrm{FeHr} / \mathrm{FeT}$ and $\mathrm{Fe} / \mathrm{Al}$ vary around a stable mean value.

Adding complexity to this story is a notable maximum in manganese (Mn) coincident with the MFS (Fig. 5b). Punctuated Mn enrichments are often interpreted as reflecting an increase in net oxidation state, such as is observed in the early Paleoproterozoic in association with the Great Oxidation Event (Holland et al., 1986; Holland, 2006). However, we note that this signature occurs within the middle of the postglacial transgressive-regressive sequence, meaning that relative water depth may play a role. Rather than indicating wholesale oxygenation, which would be in contrast to Fe data, we interpret the Mn maxima as reflecting an oxic surface ocean Mn enrichment that encroaches on the seafloor over this interval. This would require the $\mathrm{Fe}^{2+}$ content of the deeper, anoxic ocean be modest (but still ferruginous) as to not reduce the $\mathrm{Mn}$ as it settles and is deposited. This is consistent with the stable signal from other redox sensitive metals ( $\mathrm{V}, \mathrm{Ni}, \mathrm{Cr}, \mathrm{Co}, \mathrm{Cu}$ and $\mathrm{Zn}$ : Fig. 6), none of which independently suggest a mid-Sheepbed oxidation event. Chalcophile elements like Mo are notably absent from these samples, likely as a result of generally low sulfide contents rather than being related to the size of the marine redox sensitive metal reservoir. Together, the Sheepbed Formation records a relatively stable geochemical regime where deeper basinal waters were generally anoxia (and ferruginous) and controlled in large part by changes in relative sea-level and local biogeochemistry.

The increases in TOC and total P contents over the initial trangression and MFS track increases in pyrite abundance, consistent with the expectation that with a greater flux of organic carbon through the water column and to the sediments, the more heterotrophic sulfate reduction will follow. It is notably that C:P ratios are quite high, similar to that seen in the Ediacaran from Russia (Johnston et al., 2012b) and Cambrian of Australia (Creveling, personal communication), and here likely are more a function of lower relative TOC contents. That noted, the innerworkings and controls on the Neoproterozoic P cycle and deposition remain murky. The sulfur isotopic composition of pyrite provides additional insight into Ediacaran biogeochemistry. The $\delta^{34} S_{\text {sulfide }}$ is very negative in the basal Sheepbed Formation and increases systematically over the lower $\sim 100 \mathrm{~m}$ (Fig. 5a). In the upper $300 \mathrm{~m}$ of shale, $\delta^{34} \mathrm{~S}_{\text {sulfide }}$ values are always positive and often approximate that of seawater sulfate. Carbonate associated sulfate extracted from the Sheepbed carbonate carries a $\delta^{34} \mathrm{~S}$ near $30 \%$. We interpret the general change in pyrite $\delta^{34} \mathrm{~S}$ as reflecting the migration of the zone of sulfate reduction from very near the sediment water interface (sulfate replete) to some depth in the sediments. Once in the sediments, it is more realistic for sulfate to become limiting, as it would be diffusion controlled in the absence of bioturbation (Canfield and Farquhar, 2009). These fractionation patterns may also reflect changes in local sulfate reduction rates (Chambers et al., 1975; Leavitt et al., 2013). Given that TOC fluctuates wildly and does not track the $\delta^{34} \mathrm{~S}$ of pyrite, the role for variable sulfate reduction rates is, however, less likely. Finally, the progression of $\delta^{34} \mathrm{~S}$ through the lower Sheepbed Formation could be interpreted as preserving a crash in the marine $\mathrm{SO}_{4}$ pool, rather than the migration of sulfate reduction deeper into sediments. This interpretation is also not preferred, given the longer residence times of sulfate at even 5 or $10 \%$ that of the modern ocean and the expectation that the $\delta^{34} \mathrm{~S}$ of sulfate would drastically increase as the concentration dropped. Regardless, it is important to note that despite increases in pyrite abundances, $\mathrm{Fe}_{\mathrm{py}} / \mathrm{FeHr}$ remains relatively low through the entire Sheepbed Formation (Fig. 3b, c), leaving iron reduction to quantitatively outpace sulfate reduction. Surely, biogenic sulfide generated deeper in sediments will be more likely to be pyritized, perhaps explaining some of the pyrite enrichment and further linking $\delta^{34} \mathrm{~S}$ to the iron cycle.

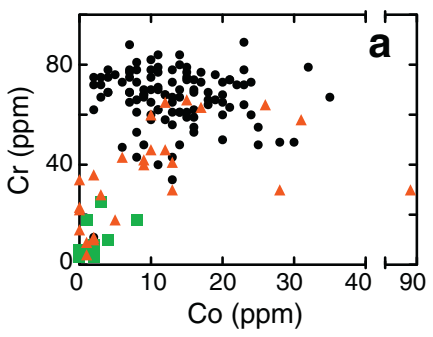

- Sheepbed Fm.

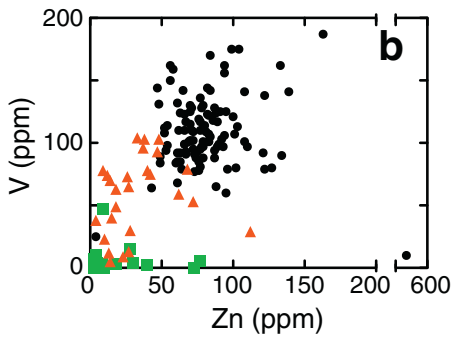

Sheepbed carbonate and Gametrail Fm.

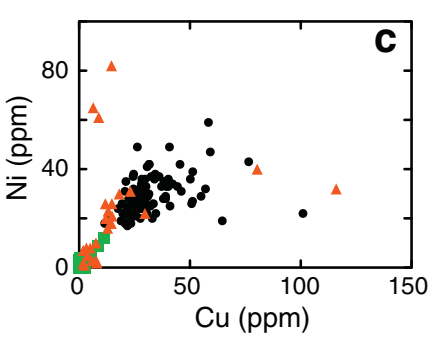

$\triangle$ Blueflower Fm.

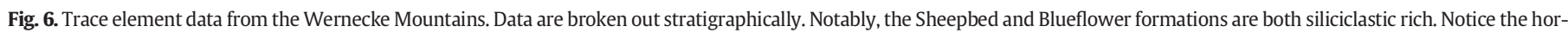
izontal scale break in frames a and b. Notably absent are enrichments in Mo, which are not plotted here and never exceed 3 ppm. 


\subsubsection{Extensions to the Mackenzie Mountains}

The interpretation of the Sheepbed Formation shale in the Wernecke Mountains can be compared to similar datasets from the Mackenzie Mountains at Shale Lake (see Figs. 1, 7a). In one such study (Shen et al., 2008b), it was argued that a distinct shift in the $\mathrm{FeHr} / \mathrm{FeT}$ at $\sim 170 \mathrm{~m}$ captured the oxygenation of the basin's water column. Because this $\mathrm{FeHr} / \mathrm{FeT}$ shift was thought to correlate to the appearance of Ediacaran fossils, primarily Aspidella from Sekwi Brook (Narbonne and Aitken, 1990b) (also within the Selwyn Mountains), this apparent Sheepbed oxygenation was interpreted to be a major driver for the biological innovation that resulted in the appearance of these organisms. Evidence for Ediacaran oxygenation in northwestern Canada is also important, because similar findings from fossil-bearing units in Newfoundland (Canfield et al., 2007), and the Eastern European platform of Russia (Johnston et al., 2012b) provide complementary tests on the linkage between animals and changes in ocean chemistry.

There are two critical considerations in deriving a basinal-scale picture of Ediacaran redox from the Mackenzie and Wernecke Mountains. Foremost, the re-correlation of both Shale Lake and Goz Creek to Sekwi Brook (the type fossil locale in the Mackenzie Mountains) now leaves all siliciclastic data from the Sheepbed Formation as underlying the first appearance of animals. This reassignment removes the tight stratigraphic correlation called upon by Shen and colleagues between a shift in $\mathrm{FeHr} / \mathrm{FeT}$ and Aspidella. There is also a methodological difference between Shen et al. and our study that lessens direct comparison. Shen et al. employed an older iron extraction method that does not isolate or quantify $\mathrm{Fe}_{\text {carb. Iron carbonate }}$ phases are perhaps the most quantitatively significant fraction in the Wernecke Mountains sections (Fig. 7b,c) and dominate a vast majority of the Neoproterozoic (Canfield et al., 2008). Fortunately, a small Sheepbed Formation sample set from the same locality as Shen et al. in the Mackenzie Mountains was published by Canfield et al. (2008) and matches quite nicely with our data from Goz Creek (Fig. 7a).

\subsection{Fingerprinting sediment protolith}

A majority of the major element data from the Sheepbed Formation follow the same first order pattern: a constant non-zero rate of change over the lower $\sim 100 \mathrm{~m}$ of the Sheepbed Formation, an inflection near the MFS, and a return to values similar to the basal Sheepbed Formation at the top of the unit. For instance, Al contents start high at the base of the section and decline modestly over the first $100 \mathrm{~m}$ of shale (also leading to lower Fe/Al: Fig. 3d). On the same length-scale, the chemical index of alteration (CIA) for the siliciclastic flux decreases from $~ 75$ to 70 over the lower $100 \mathrm{~m}$, only to climb again over the upper $200 \mathrm{~m}$ of the Sheepbed Formation back to $\sim 75$ (Fig. 5a). This trend obviously holds for $\left[\mathrm{Ca}^{2+}\right],\left[\mathrm{Mg}^{2+}\right],\left[\mathrm{Na}^{+}\right]$, and $\left[\mathrm{K}^{+}\right]$, as they contribute to the reported CIA, but is also present in TOC (wt.\%), total P, pyrite (all in Fig. 4) and exceptionally so in total manganese (Fig. 5b). Based on our reading of the Mn data, we interpret all these patterns as reflecting a first order control of water depth on the chemistry of the Sheepbed shale in the Wernecke Mountains.

Major and trace element chemistry provides significant insight into both sediment provenance and the addition of exogenous components throughout the entire Wernecke Mountain succession. Because some trace elements are known to carry signatures of carbonate mineral formation and subsequent diagenesis (McLennan and Taylor, 1991; McLennan, 1993), we target elements that are more reflective of siliciclastic deposition and whose utility as tracers (of provenance) will not be compromised by carbonate diagenesis. The elements/ oxides most reflective of siliciclastic deposition and resistant to postdepositional alteration are $\mathrm{Al}_{2} \mathrm{O}_{3}, \mathrm{~K}_{2} \mathrm{O}$, La, Sc, $\mathrm{Zr}$ and $\mathrm{Ba}$ (Taylor and McLennan, 1985; McLennan et al., 2003). These elements have often been used in studies of trace element geochemistry of carbonate rocks to detect small amounts of siliciclastic contamination (e.g., Webb and Kamber, 2000). For instance, when plotted against $\mathrm{Al}_{2} \mathrm{O}_{3}$, the elements $\mathrm{La}, \mathrm{Sc}, \mathrm{Zr}, \mathrm{Ba}$ and $\mathrm{K}_{2} \mathrm{O}$ all show strong positive correlations $\left(\mathrm{R}^{2}\right.$ ranging from 0.78 to 0.93 ) indicating detrital siliciclastic sources as the primary control on their behavior. In contrast, elements that are known or suspected to be controlled by carbonate diagenesis such as $\mathrm{Sr}$, exhibits no discernible linear trend when compared to Al.

With the effects of lithology carefully screened for, element profiles through the Wernecke Mountains section can be used to identify the influence of sedimentary components with differing provenance. The $\mathrm{La} / \mathrm{Sc}$ ratio (Fig. 8a), for example, is a useful provenance indicator because under most igneous differentiation processes, La behaves as an incompatible element and typically becomes enriched relative to the more compatible element Sc (Taylor and McLennan, 1985). Beginning with the Sheepbed Formation, $\mathrm{La} / \mathrm{Sc}$ is poised at a value typically found in shales that sample the average post-Archean upper crust (Figs. 8, 9). Well above the MFS in the Sheepbed Formation, but before fully transitioning into the Sheepbed carbonate, La/Sc sharply increases and remains at elevated and highly variable levels. High $\mathrm{La} / \mathrm{Sc}$ ratios continue through the June Beds, Gametrail Formation and into the Blueflower siliciclastics. Other measures of incompatible element enrichment, including $\mathrm{Zr} / \mathrm{Sc}$ (Fig. 8b), $\mathrm{K}_{2} \mathrm{O} / \mathrm{Al}_{2} \mathrm{O}_{3}$ (Fig. 8c) and $\mathrm{Ba} / \mathrm{Al}_{2} \mathrm{O}_{3}$
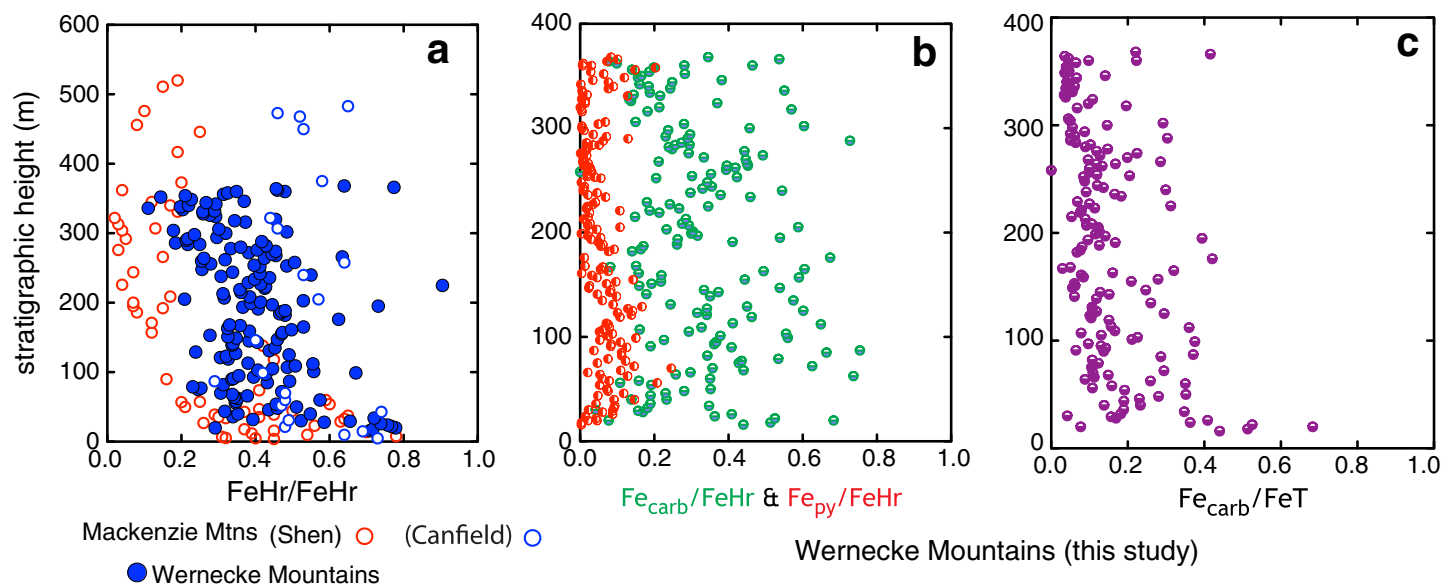

Wernecke Mountains

Wernecke Mountains (this study)

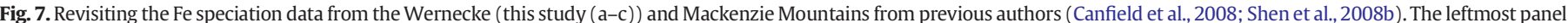

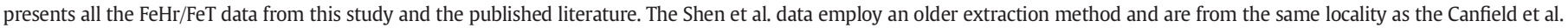

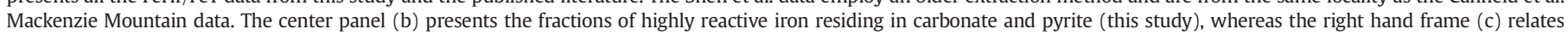
iron carbonate to total $\mathrm{Fe}$. 

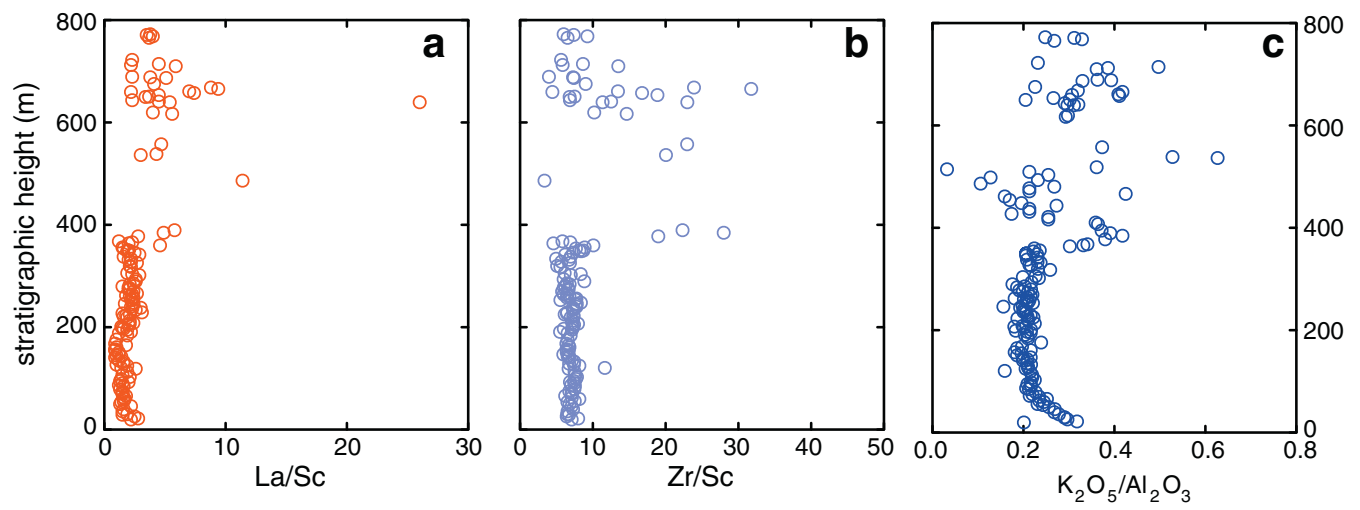

Fig. 8. Various ratios of incompatible-compatible element fractionation to diagnose siliciclastic protolith. A full description of their interpretation is included in the text.

(not shown) follow similar trends through the succession and reflect the addition of a compositionally-distinct siliciclastic component to both carbonate- and shale-dominated lithologies (Fig. 9). Importantly, this siliciclastic flux is different from that comprising the lower (majority) of Sheepbed Formation deposition, which is compositionally similar to typical post-Archean shale.

Comparisons of the various indicators of igneous differentiation show that enrichments in $\mathrm{La}, \mathrm{Zr}, \mathrm{Ba}$, and $\mathrm{K}_{2} \mathrm{O}$ can be attributed to the same component. Plots of $\mathrm{La} / \mathrm{Sc}, \mathrm{Zr} / \mathrm{Sc}$, and $\mathrm{Ba} / \mathrm{Al}_{2} \mathrm{O}_{3}$ versus $\mathrm{K}_{2} \mathrm{O} / \mathrm{Al}_{2} \mathrm{O}_{3}$ are all consistent with two-component mixing between an endmember enriched in incompatible elements and a component that is compositionally similar to the post-Archean average upper crust: PAAS (Fig. 9). These plots also highlight the differences between the lower part of the Sheepbed Formation $(<377 \mathrm{~m})$, which approximates PAAS, and the upper part of the succession, which received variable proportions of sediment from compositionally distinct sources.

The effects of chemical weathering, diagenesis and sediment provenance on major element chemistry can be evaluated in the $\mathrm{Al}_{2} \mathrm{O}_{3}-\left(\mathrm{CaO}^{*}-\mathrm{Na}_{2} \mathrm{O}\right)-\mathrm{K}_{2} \mathrm{O}$ (or $\mathrm{A}-\mathrm{CN}-\mathrm{K}$ ) geochemical system. Fig. $10 \mathrm{a}-\mathrm{C}$ compares the lower (a: <127 m) and upper (b: 127-368 m) portions of the Sheepbed Formation with siliciclastic samples from the upper
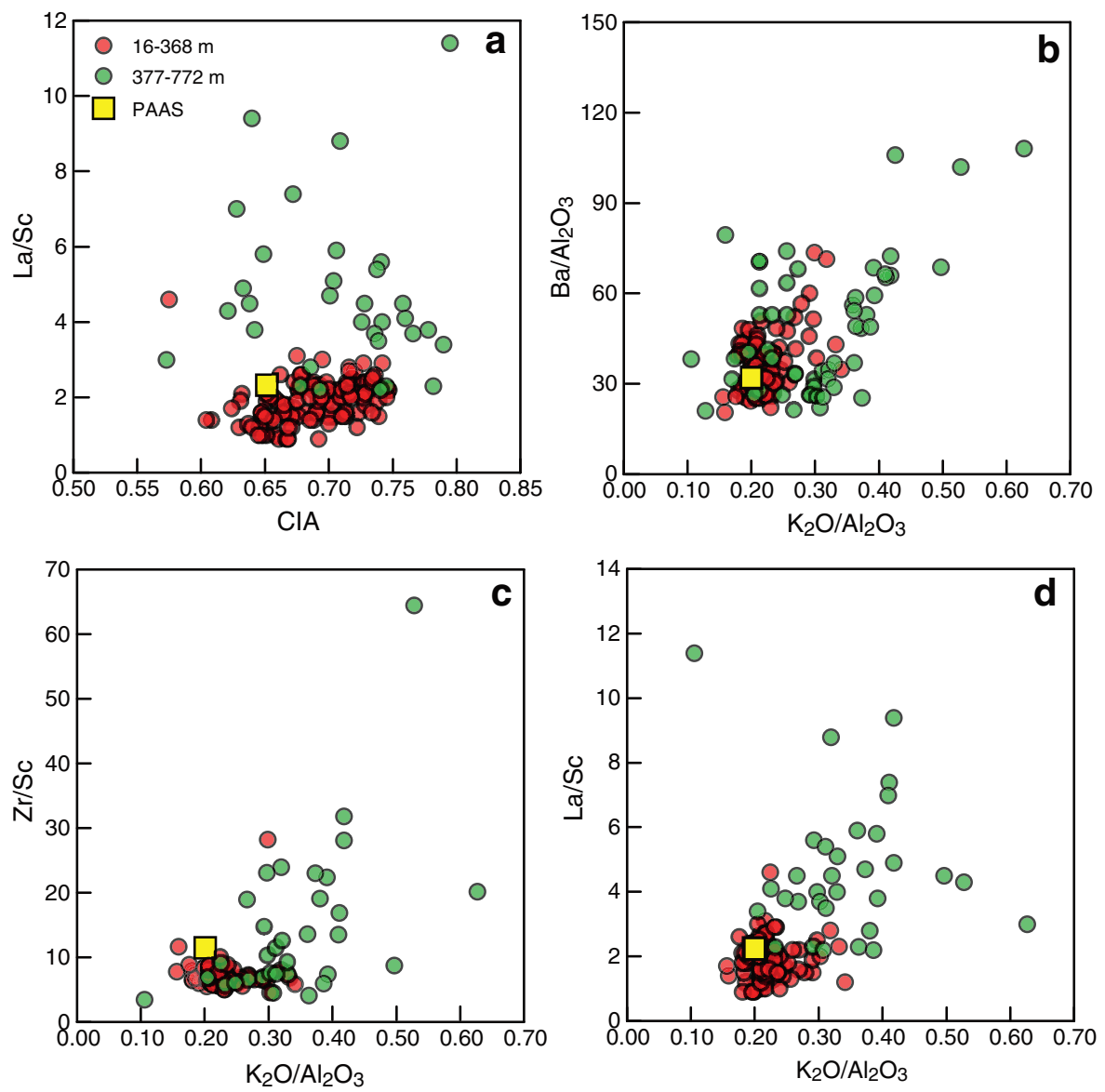

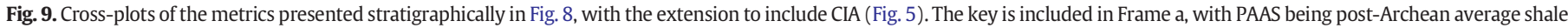

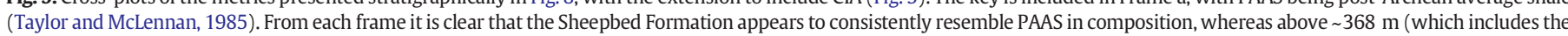
Upper Carbonate unit of the Sheepbed) the siliciclastic flux reflects mixing between a PAAS-like component and a differentiated component such as a volcanogenic ash. 


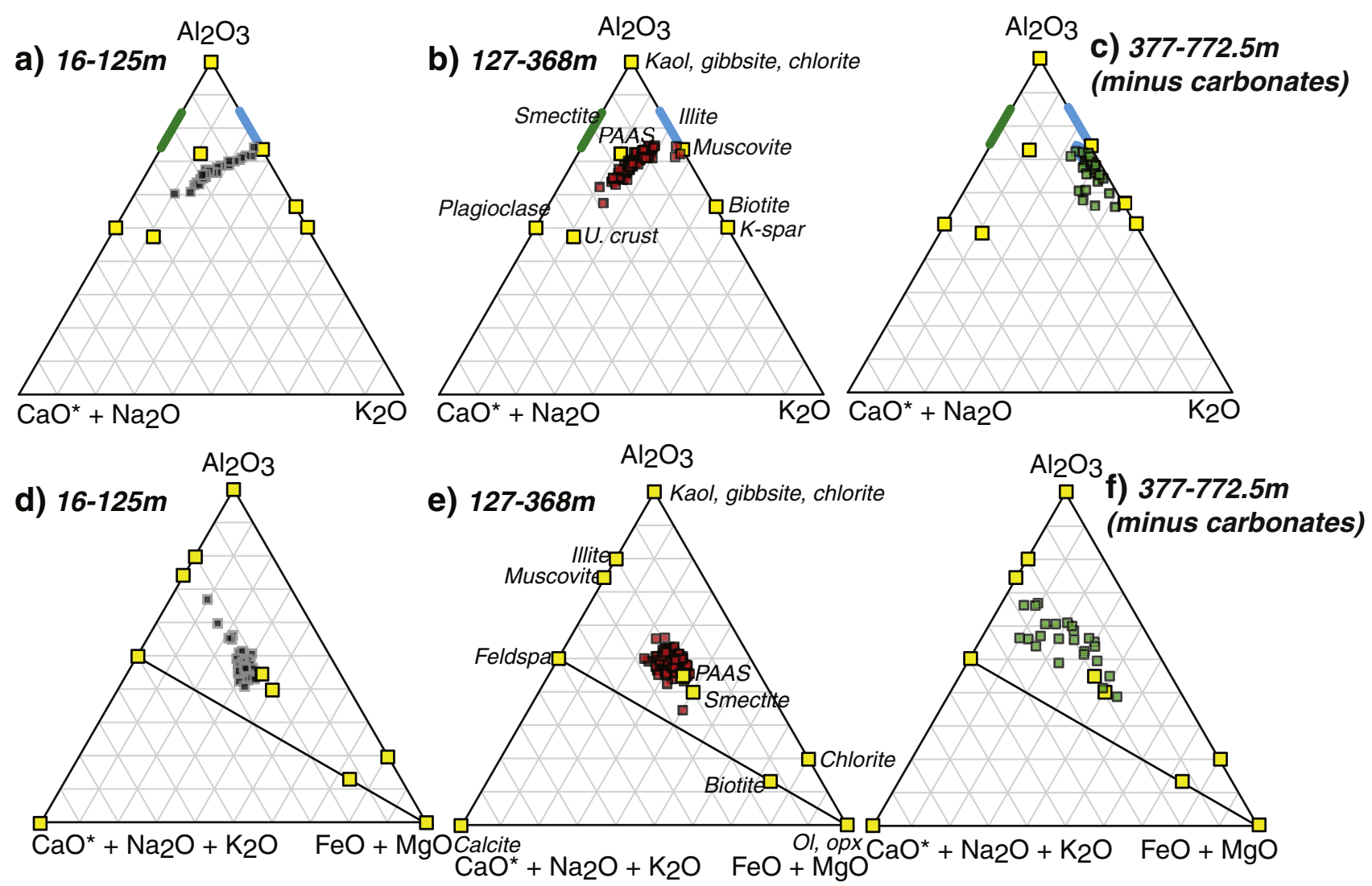

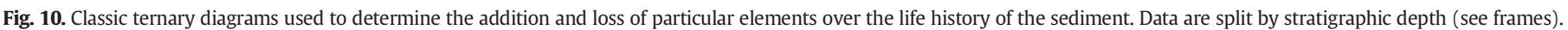

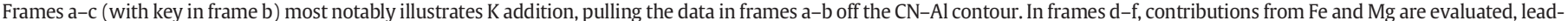
ing to the conclusion that the siliciclastics in the upper $400 \mathrm{~m}$ of stratigraphy appears similar to pure illite with variable Fe enrichment.

stratigraphy (Fig. 10c). The Sheepbed siliciclastics showing a linear trend cannot be attributed to chemical weathering alone, which typically produces trends parallel to the $\mathrm{A}-\mathrm{CN}$ join. This indicates that Sheepbed samples have suffered a minor amount of $\mathrm{K}_{2} \mathrm{O}$ addition, probably during late diagenesis, and this has pulled samples toward the $\mathrm{K}_{2} \mathrm{O}$ apex (Fedo et al., 1995). This sort of K addition is common (Tosca et al., 2010; Johnston et al., 2012b). The $>377 \mathrm{~m}$ siliciclastics (namely the Blueflower Formation), however, are chemically distinct from Sheepbed siliciclastics and nearly all are compositionally equivalent to $100 \%$ illite. Including $\mathrm{Fe}$ and $\mathrm{Mg}$ in the analysis of major element systematics (as $\mathrm{FeO}$ and $\mathrm{MgO}$, respectively: Fig. 10d-f) points to a similar distinction between Sheepbed and Blueflower siliciclastic sediments. Sheepbed Formation samples are consistent with derivation from a largely upper crustal source, whereas the Blueflower Formation samples are nearly pure illite with variable Fe enrichments (reflected by mixing between the FM apex and Fe-free illite).

Major and trace element systematics show that a highly differentiated, compositionally distinct sedimentary component is being added to this basin later in the Ediacaran. Although the highly differentiated character of this component is evident from $\mathrm{La} / \mathrm{Sc}$ ratios, enrichment in $\mathrm{Zr} / \mathrm{Sc}$ ratios (Fig. 8) can also result from the addition of highly recycled sediments that tend to concentrate heavy minerals during sediment transport (e.g., McLennan et al., 2003). Thus, $\mathrm{Zr}$ enrichment might result from the enrichment of zircon in extensively recycled sediments, but enrichments in other heavy minerals, such as ilmenite, titanite or rutile would be expected if this were the case. No Ti enrichment above average crustal levels is observed through the section. The major element characteristics of this component are also inconsistent with the addition of highly recycled sediment and instead reflect the addition of illite to siliciclastics sampling the average upper crust (Figs. 9, 10).
Taken together, incompatible element enrichment and major element chemistry indicate that the sedimentary component being added to the upper portions of the Ediacaran stratigraphy is compositionally similar to an acidic (i.e. felsic) volcanic rock. In a geochemical and isotopic study of core samples taken from the Paleoproterozoic Animikie Basin, Hemming et al. (1995) observed many of the same major and trace element characteristics in sampled ash horizons and stratigraphically proximal shale; incompatible element enrichment and major element compositions reflecting illite addition were clear geochemical indicators pointing to the influence of ash deposition on sedimentary geochemistry. However, no volcanic ashes have been identified in the field or through preliminary geochronology efforts in northwestern Canada, nor is there a detrital zircon signature of late Neoproterozoic volcanism.

The geochemical effects of this distinct siliciclastic input can be observed across a number of exposure surfaces and major unconformities. As such, this sediment source to the basin is temporally longlived, likely spanning as much as tens of millions of years depending on the amount of time lost to non-deposition. The effects of ash deposition also provide a means to reconcile the geochemical variability reflected in the upper portions of the stratigraphy in comparison to the Sheepbed Formation. For example, variable uptake and release of Fe by illite can heavily influence highly reactive and total Fe budgets, effectively providing a reactive Fe silicate pool. Typically, the deposition of volcanic ash into seawater results in the rapid alteration of volcanic glass to smectite with minor amounts of zeolite (Weaver, 1989). The exchange of major and trace elements during this process is largely a function of the initial composition of volcanic glass. In particular, Fe levels in smectite produced from volcanic ash are likely to be controlled by redox conditions in co-existing pore water as well as igneous controls on composition. Given the multiple 
lines of evidence in our samples pointing to a highly differentiated composition for volcanic components, the initial volcanic glass and the smectite produced from it are expected to be relatively Fe-poor (e.g., Weaver, 1989; Christidis and Dunham, 1997), and thus should reflect a marine Fe sink. Consistent with this interpretation, Fig. $10 \mathrm{f}$ shows considerable Fe enrichment relative to typical illite compositions, pointing to Fe addition from pore fluids as an important factor in producing relatively Fe-rich illitic compositions. Again, these changes are likely reflected in the composition of the highly reactive Fe pool, in this case biasing $\mathrm{FeHr}$ toward lower values, and would also be evident in $\mathrm{Fe} / \mathrm{Al}$. Indeed, $\mathrm{Fe} / \mathrm{Al}$ ratios are elevated in some samples, but overall quite variable, perhaps reflecting the discontinuous nature of volcanic ash addition to Blueflower siliciclastics, or the variable uptake of Fe by illite.

A change in the sedimentary sources from the Sheepbed through to the Blueflower Formation is in some fashion a predictable result of late Ediacaran rifting on the western margins of North America. As discussed elsewhere in this volume (Macdonald et al., in this issue), overlapping unconformaties and the appearance of conglomerate units in the June beds and Blueflower Formation, along with the rapid facies change to the southwest, suggest late Ediacaran extension in northwestern Canada (MacNaughton et al., 2000) and are consistent with evidence for rift-related volcanism in the southeast Canadian Cordillera (Colpron et al., 2002) and thermal subsidence models (Bond and Kominz, 1984).

\section{Conclusions and implications}

The common approach to determining paleo-redox follows from a strict, up-section reading of iron speciation records, which we complement with adjoining chemical and stratigraphic metrics. Major element chemistry and CIA interpretations from the majority of the Sheepbed Formation point to sedimentation from a common source - a protolith that appears similar to typical post-Archean shale. Iron chemistry of the Sheepbed Formation is diagnostic of an anoxic water column throughout Sheepbed deposition. However, multiple sedimentological factors, such as variable water depth or rapid infilling of accommodation space can distort and/or dilute Fe-based proxy interpretations. Despite this, the continuity between the redox signals from the lower and upper Sheepbed Formation is most conservatively interpreted as reflecting ocean chemistry. The preservation of ferruginous conditions with low sulfide contents lends to depletions in many biogeochemically important trace elements (V, Zn, and Mo; Fig. 6). Nevertheless, the MFS nicely captures a pulse of biological activity recorded by a local maximum of TOC and P contents. Manganese concentrations are elevated in the MFS, which is interpreted as a shoaling of the chemocline with ensuing contributions from an oxygenated surface ocean. Sulfur isotope records fit with the coordinated sequence stratigraphic-geochemical story, suggesting that by the time the high-stand tract was established, sulfate reduction was restricted to marine sediments and appears to be diffusion (sulfate) limited.

Whereas the Sheepbed Formation preserves a clean snapshot of the immediately post-Marinoan ocean, the later Ediacaran Blueflower and Risky formations capture a more muddled picture of the latest Proterozoic. Understanding these units is paramount, however, given the occurrence of Ediacaran fossils through this interval. That is, linking geochemistry to the fossil record in northwestern Canada provides a unique opportunity to assay the controls on early metazoan evolution. The high degree of intrinsic variability in almost every major geochemical metric $-\delta^{13} \mathrm{C}_{\mathrm{carb}}, \delta^{13} \mathrm{C}_{\mathrm{org}}, \mathrm{FeHr} / \mathrm{FeT}, \mathrm{CIA}-$ makes extracting an assuredly primary signal from the Blueflower and Risky formations difficult. However, these data show no clear sign of oxygenation. In fact, the signature of reducing, anoxic conditions is fully consistent with the inferred state of the oceans in the Sheepbed Formation. In more detail, we note that later Ediacaran metazoan preservation in the Wernecke Mountains is largely in detrital siltstone and sandstone (not clays) and thus our data closely stratigraphically bracket the actual preservation of fossiliferous material. Those bounding clays carry a composition similar to acidic volcanic rock. It remains unclear how this change in sediment protolith could influence local taphonomic or ecological conditions, but is testable in other Ediacaran, fossil-bearing strata. The most parsimonious interpretation of the late Ediacaran points to anoxia at depth up through the Precambrian-Cambrian boundary, with an uncertain tie between animals and basinal redox.

The late Neoproterozoic response of redox sensitive proxies discussed above also provides a test of whether the changes preserved in $\delta^{13} \mathrm{C}_{\text {carb }}$ of the Gametrail Formation are a local phenomenon (authigenesis) or global $\left(f_{\text {org }}\right)$ in nature. If a global oxidation event $\left(f_{\text {org }}\right)$ is robust, then the chemistry of the upper Sheepbed Formation should look markedly different to that of the Blueflower Formation (the bounding units). This is in stark opposition to most, if not all geochemical measures, which point to the infidelity of extracting and interpreting $f_{\text {org. }}$. Although siliciclastic data is not available through the putative Shuram excursion in the Gametrail Formation, the lack of a profound change in oxidation state between the Sheepbed and Blueflower formations by necessity carries the same implications for the Gametrail $\delta^{13} C_{\text {carb }}$ excursion - that is, that it does not record a quantitatively significant consumption of available oxidants.

The joined redox history of Ediacaran basins globally does show indications of localized oxygenated conditions (e.g. Newfoundland, the Eastern European Platform, and perhaps S. China), but some regions maintain evidence for anoxia throughout (northwestern Canada and portions of S. China). Some level of local control is quite possible, given variable nutrient inputs and resulting organic carbon flux to sediments (Johnston et al., 2010), but in each case, these basinal signals start with the dissolved oxygen load adopted from a well-mixed atmospheric reservoir of $\mathrm{O}_{2}$. Important to consider in these reconstructions is the remarkably low level of sulfide in siliciclastic units, indicating the possibility of a depleted seawater sulfate pool, but more likely suggesting minimal remineralization by sulfate reduction in sediments as a function of limited organic carbon delivery (Johnston et al., 2010). More surprising than the heterogeneous basinal chemistry is the lack of a strong oxygenation signal. Classic storylines call upon a major oxygenation in the Ediacaran; one that appears to be missing from many Ediacaran records.

If the classic call for a step-function change in atmospheric oxygen is not the singular motivating force for the appearance of the first metazoans (Nursall, 1959), then one of a number of issues surfaces. First, the patchy record of Ediacaran biota in basins that all carry differing geochemical signals suggests that there may exist a more nuanced physiological or ecological feature that is limiting or allowing for the move to macroscopy (Johnston et al., 2012b). As much of the redox data falls near the geochemical distinction between oxic and anoxic, perhaps an increase in $\mathrm{pO}_{2}$ is in fact housed in the Ediacaran, but that the rate or absolute magnitude of change is beneath that which we can diagnose. Resurfacing is the reality that our geochemical thresholds for 'telling $\mathrm{pO}_{2}$ ' lack the clarity to distinguish between 0.5 and $5 \% \mathrm{PAL}$, and it may be this exact range that is critical for animals (Sperling et al., 2013). Taken together, the driver for animal evolution remains elusive and although correlations can be drawn to geochemical records, the interplay between biology and chemistry is either absent (Butterfield, 2009) or more subtle than the sharpness of our geochemical tools.

These results and the preponderance of accumulating data argue against a great Ediacaran increase in atmospheric oxygen. Perhaps rather than targeting the literal reading of redox sensitive elements and counting electrons buried, as is done here and elsewhere, the exercise should be extended to more formally include 'time,' bed-by-bed analysis of fossiliferous sections, and consider the sheer volume of accumulating sediments, not only the chemical content of that sediment package. Together, this may hold the key to diagnosing both small changes in oxidation state and reveal the trigger for metazoan life. 


\section{Acknowledgments}

This paper is dedicated to Dick Holland, whose work and insight significantly shaped the field of Precambrian geochemistry and our collective understanding of the ocean-atmosphere system. We would also like to thank E. Sperling, P. Hoffman, A. Knoll, B. Gill, J.C. Creveling and four anonymous reviewers for comments on the manuscript, as well as the editorial assistance of A. Bekker. Technical support was provided by E. Beirne, G. Eischeid, T. Petach, C. Roots and A. Breus. Funding was provided by NASA NAI (DTJ, FAM), NASA Exobiology (DTJ), NSF EAR/IF (DTJ), the Yukon Geological Survey (FAM) and Harvard University. All data are available as supplemental materials.

\section{Appendix A. Supplementary data}

Supplementary data to this article can be found online at http://dx. doi.org/10.1016/j.chemgeo.2013.08.046.

\section{References}

Aitken, J.D., 1991a. 2 Late Proterozoic glaciations, Mackenzie Mountains, Northwestern Canada. Geology 19 (5), 445-448.

Aitken, J.D., 1991b. The Ice Brook Formation and Post-Rapitan, Late Proterozoic glaciation, Mackenzie Mountains, Northwest Territories. Geol. Surv. Can. Bull. 404, 1-43.

Anderson, T.F., Raiswell, R., 2004. Sources and mechanisms for the enrichment of highly reactive iron in euxinic Black Sea sediments. Am. J. Sci. 304 (3), 203-233.

Bond, G.C., Kominz, M.A., 1984. Construction of tectonic subsidence curves for the early Paleozoic Miogeocline, Southern Canadian Rocky Mountains - implications for subsidence mechanisms, age of breakup, and crustal thinning. Geol. Soc. Am. Bull. 95 (2), 155-173.

Bristow, T.F., Kennedy, M.J., 2008. Carbon isotope excursions and the oxidant budget of the Ediacaran atmosphere and ocean. Geology 36 (11), 863-866.

Broecker, W.S., 1970. A boundary condition on evolution of atmospheric oxygen. J. Geophys. Res. 75 (18), 3553-\&.

Burdett, J.W., Arthur, M.A., Richardson, M., 1989. A Neogene seawater sulfur isotope age curve from calcareous pelagic microfossils. Earth Planet. Sci. Lett. 94 (3-4), 189-198.

Butterfield, N.J., 2009. Oxygen, animals and oceanic ventilation: an alternative view. Geobiology 7 (1), 1-7.

Calver, C.R., 2000. Isotope stratigraphy of the Ediacarian (Neoproterozoic III) of the Adelaide Rift Complex, Australia, and the overprint of water column stratification. Precambrian Res. 100 (1-3), 121-150.

Canfield, D.E., 1998. A new model for Proterozoic ocean chemistry. Nature 396 (6710), 450-453.

Canfield, D.E., Farquhar, J., 2009. Animal evolution, bioturbation, and the sulfate concentration of the oceans. Proc. Natl. Acad. Sci. U. S. A. 106 (20), 8123-8127.

Canfield, D.E., Teske, A., 1996. Late Proterozoic rise in atmospheric oxygen concentration inferred from phylogenetic and sulphur-isotope studies. Nature 382 (6587), $127-132$.

Canfield, D.E., Raiswell, R., Westrich, J.T., Reaves, C.M., Berner, R.A., 1986. The use of chromium reduction in the analysis of reduced inorganic sulfurin sediments and shales. Chem. Geol. 54 (1-2), 149-155.

Canfield, D.E., Poulton, S.W., Narbonne, G.M., 2007. Late-Neoproterozoic deep-ocean oxygenation and the rise of animal life. Science 315 (5808), 92-95.

Canfield, D.E., et al., 2008. Ferruginous conditions dominated later neoproterozoic deepwater chemistry. Science 321 (5891), 949-952.

Chambers, L.A., Trudinger, P.A., Smith, J.W., Burns, M.S., 1975. Fractionation of sulfur isotopes by continuous cultures of Desulfovibrio desulfuricans. Can. J. Microbiol. 21 (10), 1602-1607.

Christidis, G., Dunham, A.C., 1997. Compositional variations in smectites. 2. Alteration of acidic precursors, a case study from Milos island, Greece. Clay Miner. 32 (2) 253-270.

Cloud, P.E., Drake, E.T., 1968. Pre-metazoan evolution and the origins of the Metazoa. Evolution and Environment: A Symposium, pp. 1-72.

Colpron, M., Logan, J.M., Mortensen, J.K., 2002. U-Pb zircon age constraint for late Neoproterozoic rifting and initiation of the lower Paleozoic passive margin of western Laurentia. Can. J. Earth Sci. 39 (2), 133-143.

Corsetti, F.A., Kaufman, A.J., 2003. Stratigraphic investigations of carbon isotope anomalies and Neoproterozoic ice ages in Death Valley, California. Geol. Soc. Am. Bull. 115 (8), 916-932.

Dalrymple, R.W., Narbonne, G.M., 1996. Continental slope sedimentation in the Sheepbed Formation (Neoproterozoic, Windermere Supergroup), Mackenzie Mountains, N.W.T. Canadian Journal of Earth Sciences 33, 848-862.

Day, E.S., James, N.P., Narbonne, G.M., Dalrymple, R.W., 2004. A sedimentary prelude to marinoan glaciation, Cryogenian (Middle Neoproterozoic) Keele Formation, Mackenzie Mountains, northwestern Canada. Precambrian Res. 133 (3-4), 223-247.

DesMarais, D.J., Strauss, H., Summons, R.E., Hayes, J.M., 1992. Carbon isotope evidence for the stepwise oxidation of the Proterozoic environment. Nature 359 (6396) 605-609.
Fedo, C.M., Nesbitt, H.W., Young G.M., 1995. Unraveling the effects of Potassium metasomatism in sedimentary-rocks and paleosols, with implications for paleoweathering conditions and provenance. Geology 23 (10), 921-924.

Fedonkin, M.A., Waggoner, B.M., 1997. The Late Precambrian fossil Kimberella is a mollusc-like bilaterian organism. Nature 388 (6645), 868-871.

Fike, D.A., Grotzinger, J.P., 2008. A paired sulfate-pyrite delta S-34 approach to understanding the evolution of the Ediacaran-Cambrian sulfur cycle. Geochim. Cosmochim. Acta 72 (11), 2636-2648.

Fike, D.A., Grotzinger, J.P., Pratt, L.M., Summons, R.E., 2006. Oxidation of the Ediacaran Ocean. Nature 444 (7120), 744-747.

Gill, B.C., Lyons, T.W., Saltzman, M.R., 2007. Parallel, high-resolution carbon and sulfur isotope records of the evolving Paleozoic marine sulfur reservoir. Palaeogeogr. Palaeoclimatol. Palaeoecol. 256 (3-4), 156-173.

Grey, K., 2005. Ediacaran palynology of Australia. Mem. Assoc. Australas. Palaeontol. 31, $1-439$.

Grotzinger, J.P., Fike, D.A., Fischer, W.W., 2011. Enigmatic origin of the largest-known carbon isotope excursion in Earth's history. Nat. Geosci. 4 (5), 285-292.

Halverson, G.P., Hoffman, P.F., Schrag, D.P., Maloof, A.C., Rice, A.H.N., 2005. Toward a Neoproterozoic composite carbon-isotope record. Geol. Soc. Am. Bull. 117 (9-10), $1181-1207$

Hayes, J.M., Waldbauer, J.R., 2006. The carbon cycle and associated redox processes through time. Philos. Trans. R. Soc. B-Biol. Sci. 361 (1470), 931-950.

Hayes, J.M., Strauss, H., Kaufman, A.J., 1999. The abundance of C-13 in marine organic matter and isotopic fractionation in the global biogeochemical cycle of carbon during the past $800 \mathrm{Ma}$. Chem. Geol. 161 (1-3), 103-125.

Hemming, S.R., McLennan, S.M., Hanson, G.N., 1995. Geochemical and Nd/Pb isotopic evidence for the provenance of the early proterozoic Virginia formation. Minnesota. Implications for the tectonic setting of the Animikie basin. The Journal of Geology 103, 147-168.

Higgins, J.A., Schrag, D.P., 2003. Aftermath of a snowball Earth. Geochem. Geophys. Geosyst. 4

Hoffman, P.F., Halverson, G.P., 2011. Neoproterozoic glacial record in the Mackenzie Mountains, northern Canadian Cordillera. In: Arnaud, E. Halverson, G.P. ShieldsZhou, G. (Eds.), The Geological Record of Neoproterozoic Glaciations. The Geological Society, London, pp. 397-412.

Hoffman, P.F., et al., 2007. Are basal Ediacaran (635 Ma) post-glacial "cap dolostones" diachronous? Earth Planet. Sci. Lett. 258 (1-2), 114-131.

Hofmann, H.J., Narbonne, G.M., Aitken, J.D., 1990. Ediacaran remains from intertillite Beds in Northwestern Canada. Geology 18 (12), 1199-1202.

Holland, H.D., 1984. Chemical Evolution of the Atmosphere and Ocean. Princeton University Press (598 pp.)

Holland, H.D., 2006. The oxygenation of the atmosphere and oceans. Philos. Trans. R. Soc, B-Biol. Sci. 361 (1470), 903-915.

Holland, H.D., Lazar, B., McCaffrey, M., 1986. Evolution of the atmosphere and oceans. Nature 320 (6057), 27-33.

James, N.P., Narbonne, G.M., Kyser, T.K., 2001. Late Neoproterozoic cap carbonates: Mackenzie Mountains, northwestern Canada: precipitation and global glacial meltdown. Can. J. Earth Sci. 38 (8), 1229-1262.

Johnston, D.T., et al., 2010. An emerging picture of Neoproterozoic ocean chemistry: insights from the Chuar Group, Grand Canyon, USA. Earth Planet. Sci. Lett. 290 (1-2), $64-73$

Johnston, D.T., Macdonald, F.A., Gill, B.C., Hoffman, P.F., Schrag, D.P., 2012a. Uncovering the Neoproterozoic carbon cycle. Nature 483 (7389), 320-U110.

Johnston, D.T., et al., 2012b. Late Ediacaran redox stability and metazoan evolution. Earth Planet. Sci. Lett. (335-336), 25-35.

Kah, L.C., Bartley, J.K., 2011. Protracted oxygenation of the Proterozoic biosphere. Int. Geol. Rev. 53 (11-12), 1424-1442.

Kampschulte, A., Strauss, H., 2004. The sulfur isotopic evolution of Phanerozoic seawater based on the analysis of structurally substituted sulfate in carbonates. Chem. Geol. 204 (3-4), 255-286.

Kaufman, A.J., Knoll, A.H., Narbonne, G.M., 1997. Isotopes, ice ages, and terminal Proterozoic earth history. Proc. Natl. Acad. Sci. U. S. A. 94 (13), 6600-6605

Knoll, A.H., Walter, M.R., 1992. Latest Proterozoic stratigraphy and Earth history. Nature 356 (6371), 673-678.

Knoll, A.H., Hayes, J.M., Kaufman, A.J., Swett, K., Lambert, I.B., 1986. Secular variation in carbon isotope ratios from upper Proterozoic successions of Svalbard and east Greenland. Nature 321 (6073), 832-838.

Kronberg, B.I., Nesbitt, H.W., Lam, W.W., 1986. Upper Pleistocene Amazon deep-sea fan muds reflect intense chemical-weathering of their mountainous source lands. Chem. Geol. 54 (3-4), 283-294.

Leavitt, W.D., Bradley, A.S., Halevy, I., Johnston, D.T., 2013. Calibrating the Phanerozoic S Cycle: Multiple S Isotopes as a Vehicle to Access Sulfate Reduction Rates and Organic Carbon Delivery to Sediments Proceedings of the National Academy of Science.

Li, C., et al., 2010. A Stratified Redox Model for the Ediacaran Ocean. Science 328 (5974), $80-83$.

Lyons, T.W., Severmann, S., 2006. A critical look at iron paleoredox proxies: new insights from modern euxinic marine basins. Geochim. Cosmochim. Acta 70 (23), 5698-5722.

Macdonald, F.A., et al., 2013. The stratigraphic relationship between the Shuram carbon isotope excursion, the oxygenation of Neoproterozoic oceansm and the first appearence of the Ediacara biota and bilaterian trace fossils in northwest Canada. Chem. Geol. (in this issue)

MacNaughton, R.B., Narbonne, G.M., Dalrymple, R.W., 2000. Neoproterozoic slope deposits, Mackenzie Mountains, northwestern Canada: implications for passivemargin development and Ediacaran faunal ecology. Can. J. Earth Sci. 37 (7), 997-1020. 
McFadden, K.A., et al., 2008. Pulsed oxidation and bioloical evolution in the Ediacaran Doushantuo Formation. Proc. Natl. Acad. Sci. U. S. A. 105 (9), 3197-3202.

McLennan, S.M., 1993. Weathering and global denudation. J. Geol. 101 (2), 295-303.

McLennan, S.M., Taylor, S.R., 1991. Sedimentary-rocks and crustal evolution - tectonic setting and secular trends. J. Geol. 99 (1), 1-21.

McLennan, S.M., et al., 2003. The roles of provenance and sedimentary processes in the geochemistry of sedimentary rocks. In: Lentz, D.R. (Ed.), Geochemistry of Sediments and Sedimentary Rocks: Evolutionary Considerations to Mineral Deposit-forming Environments. Geological Association of Canada, pp. 7-38.

Narbonne, G.M., Aitken, J.D., 1990a. Ediacaran fossils from the Sekwi Brook area, Mackenzie Mountains, northwest Canada. Palaentology 33 (4), 945-980.

Narbonne, G.M., Aitken, J.D., 1990b. Ediacaran fossils from the Sekwi Brook Area, Mackenzie Mountains, Northwestern Canada. Palaeontology 33, 945-980.

Narbonne, G.M., Kaufman, A.J., Knoll, A.H., 1994. Integrated chemostrigraphy and biostratigraphy of the Windmere Supergroup, northwestern Canada - implications for Neoproterozoic correlations and the early evolution of animals. Geol. Soc. Am. Bull. 106 (10), 1281-1292.

Nowlan, G.S., Narbonne, G.M., Fritz, W.H., 1985. Small shelly fossils and trace fossils near the Precambrian Cambrian boundary in the Yukon Territory, Canada. Lethiaia 18, 233-256.

Nursall, J.R., 1959. Oxygen as a prerequisite to the origin of the Metazoa. Nature 183 (4669), 1170-1172.

Och, L.M., Shields-Zhou, G.A., 2012. The Neoproterozoic oxygenation event: environmental perturbations and biogeochemical cycling. Earth Sci. Rev. 110 (1-4), 26-57.

Planavsky, N.J., et al., 2011. Widespread iron-rich conditions in the mid-Proterozoic ocean. Nature 477 (7365), 448-U95.

Poulton, S.W., Canfield, D.E., 2005. Development of a sequential extraction procedure for iron: implications for iron partitioning in continentally derived particulates. Chem. Geol. 214 (3-4), 209-221.

Poulton, S.W., Canfield, D.E., 2011. Ferruginous conditions: a dominant feature of the ocean through Earth's history. Elements 7 (2), 107-112.

Poulton, S.W., Raiswell, R., 2002. The low-temperature geochemical cycle of iron: from continental fluxes to marine sediment deposition. Am. J. Sci. 302 (9), $774-805$.

Poulton, S.W., Fralick, P.W., Canfield, D.E., 2004. The transition to a sulphidic ocean similar to 1.84 billion years ago. Nature 431 (7005), 173-177.

Poulton, S.W., Fralick, P.W., Canfield, D.E., 2010. Spatial variability in oceanic redox structure 1.8 billion years ago. Nat. Geosci. 3 (7), 486-490.
Pyle, L.J., Narbonne, G.M., James, N.P., Dalrymple, R.W., Kaufman, A.J., 2004. Integrated Ediacaran chronostratigraphy, Wernecke Mountains, northwestern Canada. Precambrian Res. 132 (1-2), 1-27.

Pyle, L.J., Narbonne, G.M., Nowlan, G.S., Xiao, S., James, N.P., 2006. Early Cambrian metazoan eggs, embryos, and phosphatic microfossils from northwestern Canada. J. Paleontol. 80 (5), 811-825.

Raff, R.A., Raff, E.C., 1970. Respiratory mechanisms and metazoan fossil record. Nature 228 (5275), 1003-\&.

Raiswell, R., Canfield, D.E., 1998. Sources of iron for pyrite formation in marine sediments. Am. J. Sci. 298 (3), 219-245.

Rothman, D.H., Hayes, J.M., Summons, R.E., 2003. Dynamics of the Neoproterozoic carbon cycle. Proc. Natl. Acad. Sci. U. S. A. 100 (14), 8124-8129.

Runnegar, B., 1991. Precambrian oxygen levels estimated from the biochemistry and physiology of early eukaryotes. Palaeogeogr. Palaeoclimatol. Palaeoecol. 97 (1-2), 97-111.

Sahoo, S.K., et al., 2012. Ocean oxygenation in the wake of the Marinoan glaciation. Nature 489 (7417), 546-549.

Schrag, D.P., Higgins, J.A., Macdonald, F.A., Johnston, D.T., 2013. Authigenic carbonate and the history of the global carbon cycle. Science 339 (6119), 540-543.

Scott, C., et al., 2008. Tracing the stepwise oxygenation of the Proterozoic ocean. Nature 452 (7186), 456-U5.

Shen, B., et al., 2008a. Stratification and mixing of a post-glacial Neoproterozoic ocean: evidence from carbon and sulfur isotopes in a cap dolostone from northwest China. Earth Planet. Sci. Lett. 265 (1-2), 209-228.

Shen, Y.N., Zhang, T.G., Hoffman, P.F., 2008b. On the coevolution of Ediacaran oceans and animals. Proc. Natl. Acad. Sci. U. S. A. 105 (21), 7376-7381.

Sperling, Erik A., Halverson, Galen P., Knoll, Andrew H., Macdonald, Francis A., Johnston, David T., 2013. A basin redox transect at the dawn of animal life. Earth and Planetary Science Letters 371-372, 143-155.

Taylor, S.R., McLennan, S.M., 1985. The Continental Crust: Its Composition and Evolution. Blackwell (312 pp.).

Tosca, N.J., et al., 2010. Clay mineralogy, organic carbon burial, and redox evolution in Proterozoic oceans. Geochim. Cosmochim. Acta 74 (5), 1579-1592.

Weaver, C.E., 1989. Clays, muds, and shales. Developments in Sedimentology.Elsevier, New York (819 pp).

Webb, G.E., Kamber, B.S., 2000. Rare earth elements in Holocene reefal microbialites: new shallow seawater proxy. Geochim. Cosmochim. Acta 64 (9), 1557-1565.

Workman, R.K., Grotzinger, J.P., Hart, S.R., 2002. Constraints on Neoproterozoic ocean chemistry from delta C-13 and delta B-11 analyses of carbonates from the Witvle and Nama Groups, Namibia. Geochim. Cosmochim. Acta 66 (15A), A847-A847. 